\title{
Surveillance of Site A and Plot M Report for 2003
}

\author{
Norbert W. Golchert \\ The Office of ESH/QA Oversight
}

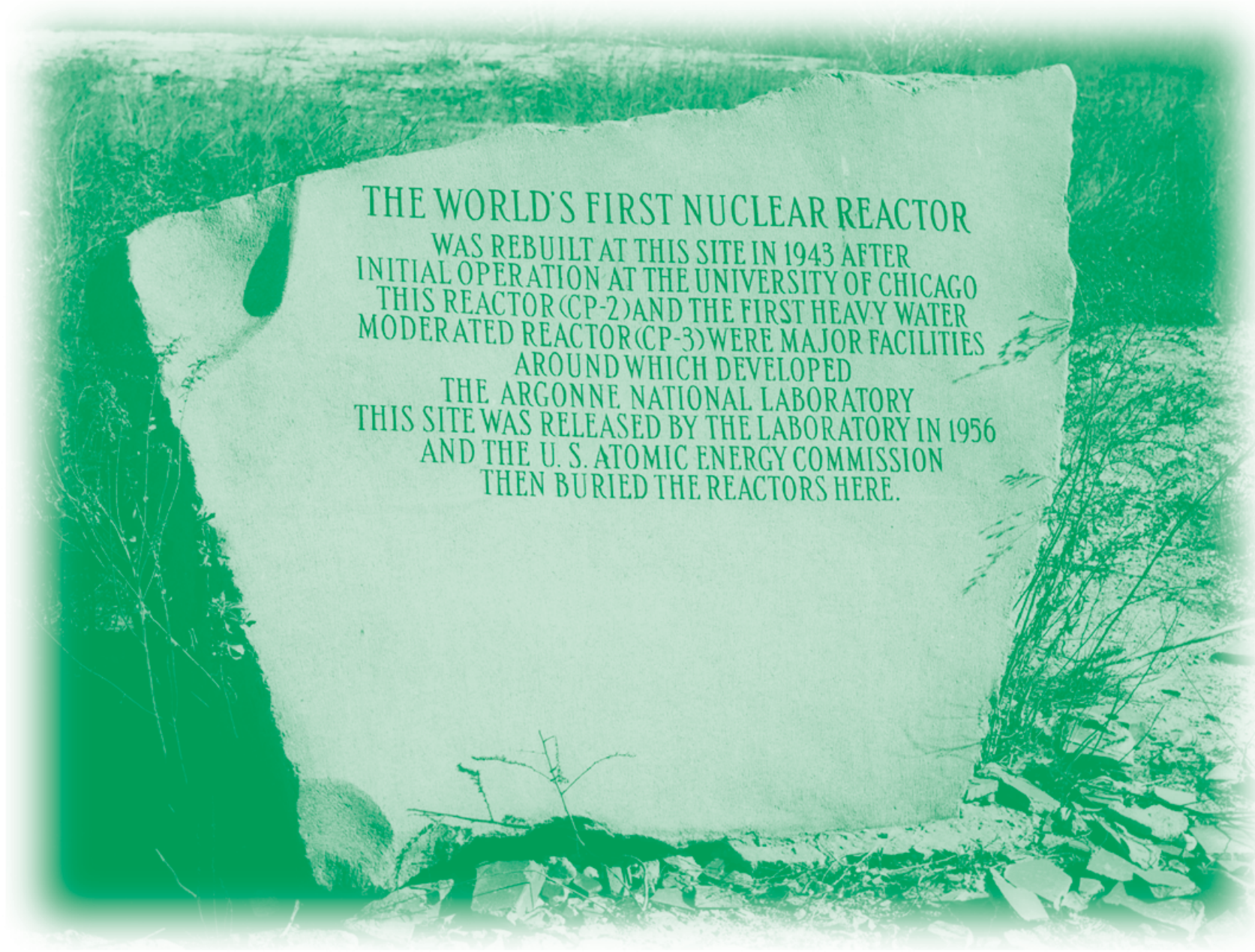

Argonne National Laboratory, Argonne, Illinois 60439 operated by The University of Chicago

for the United States Department of Energy under Contract W-31-109-Eng-38 
Argonne National Laboratory, a U.S. Department of Energy Office of Science laboratory, is operated by The University of Chicago under contract W-31-109-Eng-38.

DISCLAIMER
This report was prepared as an account of work sponsored by an agency of
the United States Government. Neither the United States Government nor
any agency thereof, nor The University of Chicago, nor any of their
employees or officers, makes any warranty, express or implied, or assumes
any legal liability or responsibility for the accuracy, completeness, or
usefulness of any information, apparatus, product, or process disclosed, or
represents that its use would not infringe privately owned rights. Reference
herein to any specific commercial product, process, or service by trade name,
trademark, manufacturer, or otherwise, does not necessarily constitute or
imply its endorsement, recommendation, or favoring by the United States
Government or any agency thereof. The views and opinions of document
authors expressed herein do not necessarily state or reflect those of the
United States Government or any agency thereof.

Available electronically at http://www.osti.gov/bridge/

Available for a processing fee to U.S. Department of Energy and its contractors, in paper, from:

U.S. Department of Energy

Office of Scientific and Technical Information

P.O. Box 62

Oak Ridge, TN 37831-0062

phone: (865) 576-8401

fax: (865) 576-5728

email: reports@adonis.osti.gov 
ANL-04/1

ARGONNE NATIONAL LABORATORY-EAST

9700 South Cass Avenue

Argonne, Illinois 60439

\section{SURVEILLANCE OF SITE A AND PLOT M}

Report for 2003

by

Norbert W. Golchert

The Office of ESH/QA Oversight

May 2004

Prepared for the U. S. Department of Energy

Work Package ANL 0350004 -- WBS No. AH-10-05-121I 


\title{
PREFACE
}

This report is prepared for the U. S. Department of Energy (DOE) by the Office of ESH/QA Oversight (EQO) at Argonne National Laboratory-East (ANL-E). The results of the environmental monitoring program at Site A and Plot M and an assessment of the impact of the site on the environment and the public are presented in this publication. Funding to support this program was provided by the Office of Environmental Management through the U. S. Department of Energy Grand Junction Office. This report and some earlier issues of the annual reports are available on the Internet at http://www.anl.gov/ESH/sitea.

Most of the tables and some of the figures were prepared by Jennifer Tucker of the Data Management Team. Sample collection and field measurements were conducted under the direction of Ronald Kolzow of the EQO Environmental Monitoring and Surveillance Group by:

\author{
Tony Fracaro \\ Dan Milinko \\ Rob Piorkowski
}

The analytical separations and measurements were conducted by the EQO Analytical Services Laboratory:

Tim Branch

Theresa Davis

Alan Demkovich

Christopher Gierek

Richard Kasper
James Riha

Denise Seeman

Christos Stamoudis

Emmer Thompson

John Zhang

This manuscript was typed and prepared for publication by Elaine M. London (EQO). 


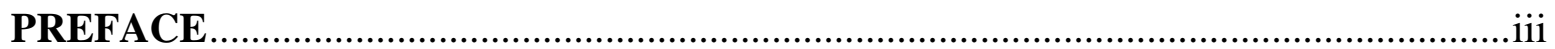

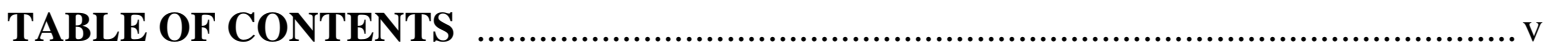

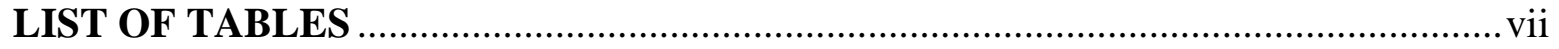

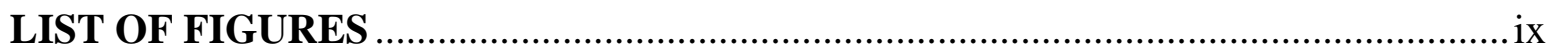

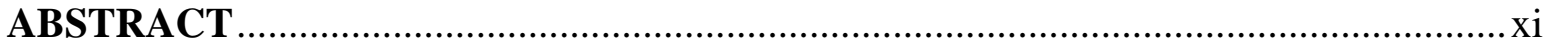

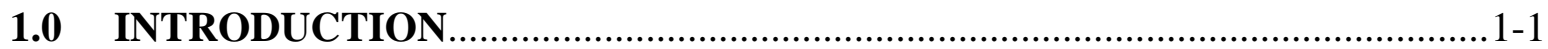

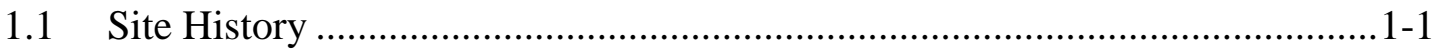

1.2 Site Characteristics .............................................................................. 1-5

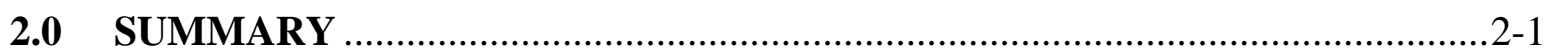

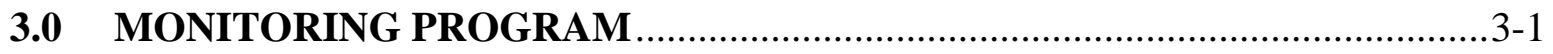

3.1 Surface Water.........................................................................................

3.2 Subsurface Water .....................................................................................

3.2.1 Borehole Water - Plot M...................................................................... 3-5

3.2.2 Borehole Water - Site A..................................................................

3.2.3 Dolomite Hole Water.........................................................................

3.2.4 Well Water ........................................................................................

4.0 SUMMARY OF POTENTIAL RADIATION DOSE

AND RISK ESTIMATES ................................................................................4-1

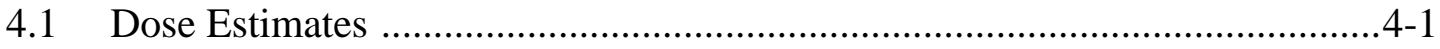

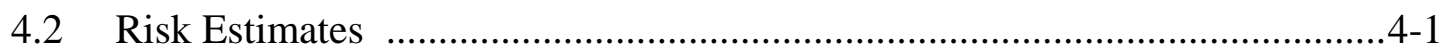

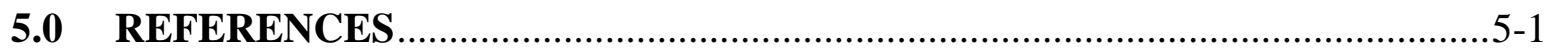




\section{TABLE OF CONTENTS (Contd.)}

$\underline{\text { Page }}$

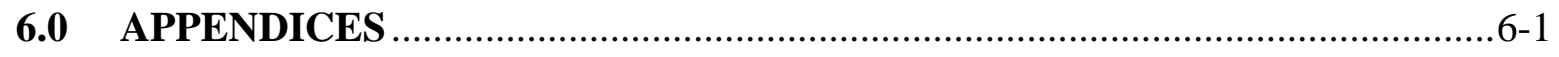

6.1 Quality Assurance Program .....................................................................6-1

6.2 Applicable Standards ............................................................................6-2

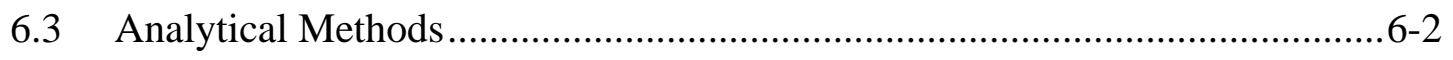

6.4 Distribution for ANL-04/1 ................................................................. 6-3 


\section{LIST OF TABLES}

No.

$\underline{\text { Title }}$

$\underline{\text { Page }}$

3.1 Hydrogen-3 Content of Stream Next to Plot M, 2003 ..........................................3-4

3.2 Hydrogen-3 in Plot M Borehole Water, 2003.....................................................

3.3 Water Level Measurements in Boreholes Near

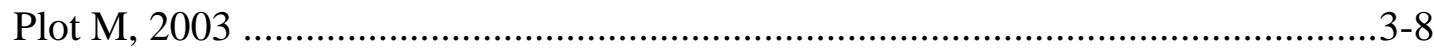

3.4 Strontium-90 Content of Borehole Water Samples

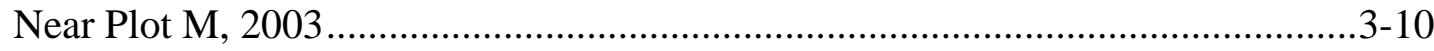

3.5 Hydrogen-3 in Site A Borehole Water, 2003 ...................................................3-13

3.6 Water Level Measurements in Boreholes Near

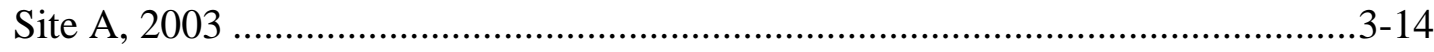

3.7 Strontium-90 Content of Borehole Water Samples Near Site A, 2003 ..................3-15

3.8 Hydrogen-3 in Dolomite Holes, 2003.......................................................... $3-18$

3.9 Water Level Measurements in Dolomite Holes, 2003........................................3-19

3.10 Hydrogen-3 Content of Wells Near Site A/Plot M, 2003 ...................................3-22

3.11 Annual Maximum and Average Hydrogen-3 Concentrations in the Red Gate Woods Wells....

4.1 Dose From Continuous Exposure to Hydrogen-3 at Selected Locations, 2003 ............................................................................. 4

4.2 Estimates of Hydrogen-3 Exposures to a Casual Visitor to Plot M, 2003...............4-3

4.3 Annual Average Dose Equivalent in the U. S. Population ....................................4-4

4.4 Risk of Death From Various Events ................................................................4-6 


\section{LIST OF FIGURES}

No.

1.1 Location of Palos Forest Preserve on Chicago-Area Map .....................................1-2

1.2 Palos Forest Preserve Showing Location of Site A/Plot M Dolomite Holes and Picnic Wells........................................................................

3.1 Surface Water Sampling Locations Near Plot M .................................................3-3

3.2 Map of Plot M Palos Site Showing Topography, Intermittent Stream, and Borehole Locations......................................................

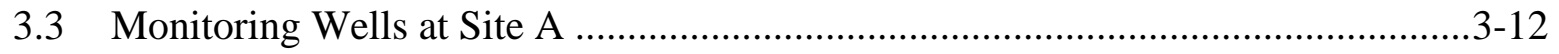

3.4 Locations of Dolomite Holes North of Plot M ......................................................17

3.5 Hydrogen-3 Concentrations in Opposite Red Gate Woods (\#5159) and Red Gate Woods North (\#5160) Wells From 1993 Through 2003 


\title{
SURVEILLANCE OF SITE A AND PLOT M
}

Report for 2003

by

Norbert W. Golchert

\begin{abstract}
The results of the environmental surveillance program conducted at Site A/Plot M in the Palos Forest Preserve area for Calendar Year 2003 are presented. Based on the results of the 1976-1978 radiological characterization of the site, a determination was made that a surveillance program be established. The characterization study determined that very low levels of hydrogen-3 (as tritiated water) had migrated from the burial ground and were present in two nearby handpumped picnic wells. The current surveillance program began in 1980 and consists of sample collection and analysis of surface and subsurface water. The results of the analyses are used to 1) monitor the migration pathway of water from the burial ground (Plot $\mathrm{M}$ ) to the handpumped picnic wells, 2) establish if buried radionuclides other than hydrogen-3 have migrated, and 3) monitor the presence of radioactive and chemically hazardous materials in the environment of the area. Hydrogen-3 in the Red Gate Woods picnic wells was still detected this year, but the average and maximum concentrations were significantly less than found earlier. Hydrogen-3 continues to be detected in a number of wells, boreholes, dolomite holes, and a surface stream. Analyses since 1984 have indicated the presence of low levels of strontium-90 in water from a number of boreholes next to Plot $\mathrm{M}$. The results of the surveillance program continue to indicate that the radioactivity remaining at Site A/Plot $\mathrm{M}$ does not endanger the health or safety of the public visiting the site, using the picnic area, or living in the vicinity.
\end{abstract}




\subsection{INTRODUCTION}

\subsection{Site History}

This report presents and discusses the surveillance data obtained during 2003. The surveillance program is the ongoing activity that resulted from the 1976-1978 radiological characterization of the former site of Argonne National Laboratory and its predecessor, the University of Chicago's Metallurgical Laboratory. This site was part of the World War II Manhattan Engineer District Project and was located in the Palos Forest Preserve southwest of Chicago, IL. The Laboratory used two locations in the Palos Forest Preserve: Site A, a 19-acre area that contained experimental laboratories and nuclear reactor facilities; and Plot M, a $150 \mathrm{ft}$ x $140 \mathrm{ft}$ area used for the burial of radioactive waste. These locations are shown in Figure 1.1 and Figure 1.2. Previous comprehensive reports on this subject ${ }^{1,2}$ provide additional detail and illustrations on sampling locations and provide descriptive material along with the results through 1981 . There are

annual reports for 1982 through 2002. ${ }^{3-23}$ While earlier data will not be repeated in this report, reference is made to some of the results.

Operations at Site A began in 1943 and ceased in 1954. Among the research programs carried out at Site A were reactor physics studies, fission product separations, hydrogen-3 recovery from irradiated lithium, and work related to the metabolism of radionuclides in laboratory animals. Radioactive waste and radioactively-contaminated laboratory articles from these studies were buried at Plot M. At the termination of the programs, the reactor fuel and heavy water, used for neutron moderation and reactor cooling, were removed and shipped to Oak Ridge National Laboratory. The biological shield for the CP-3 reactor located at Site A, together with various pipes, valves, and building debris, was buried in place in 1956. 


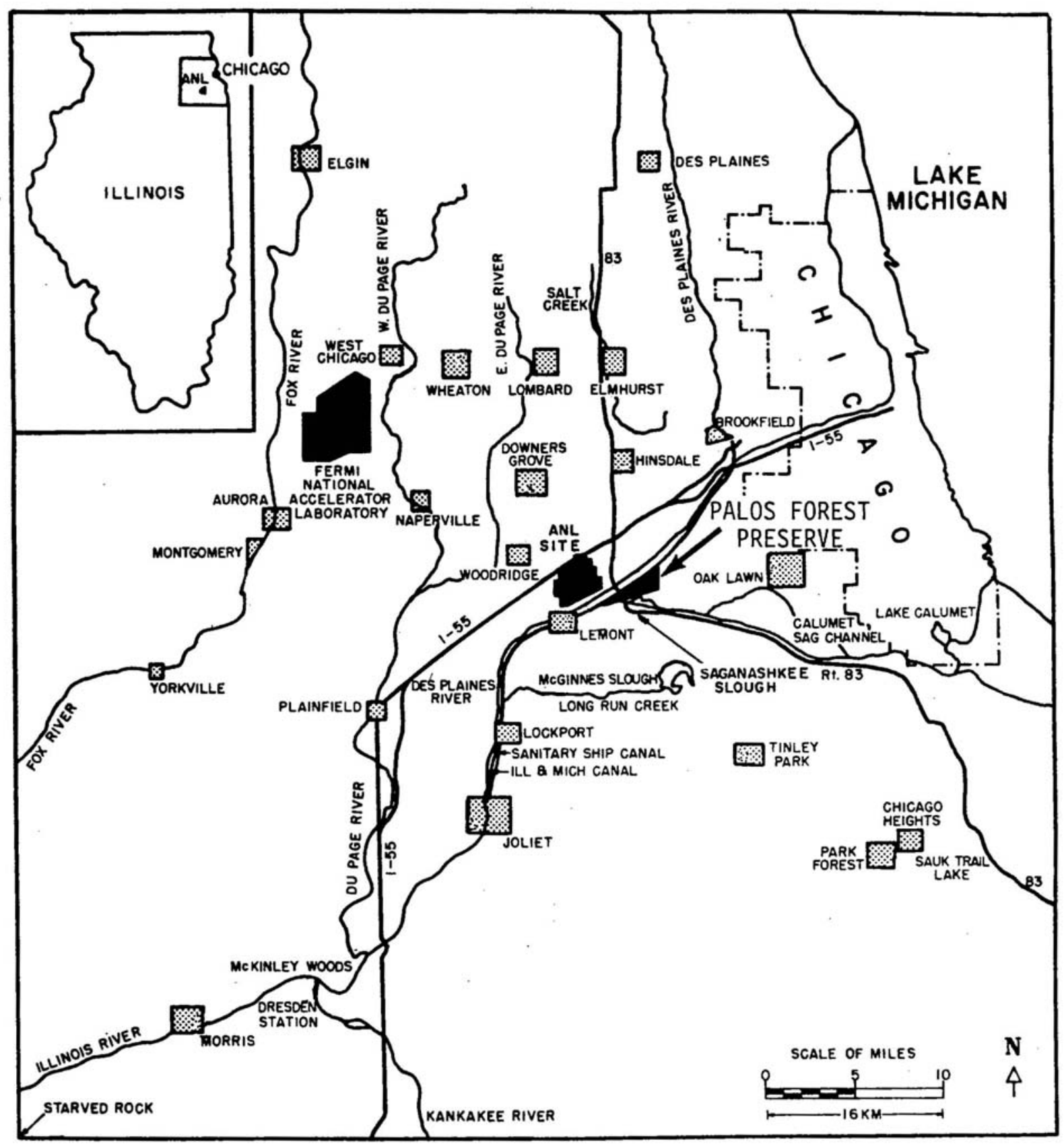

Figure 1.1 Location of Palos Forest Preserve on Chicago-Area Map 


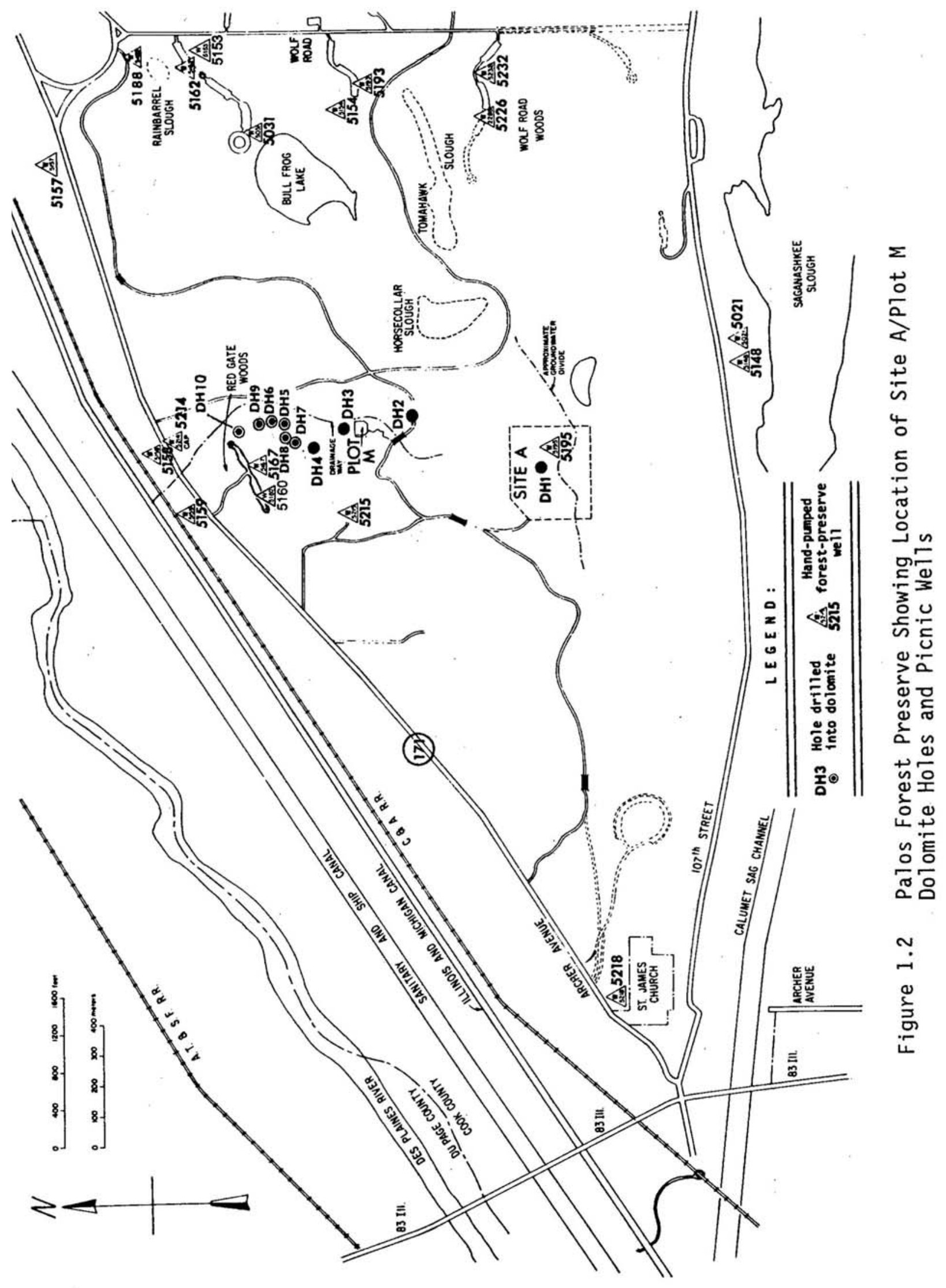


Burial of radioactive waste at Plot M began in 1944 and was discontinued in 1949. Waste was buried in six-foot deep trenches and covered with soil until 1948, after which, burial took place in steel bins. The steel bins were removed in 1949 and sent to Oak Ridge National Laboratory for disposal, but the waste buried in trenches was allowed to remain in place. Concrete sidewalls, eight feet deep, were poured around the perimeter of the burial area and a one-foot thick reinforced concrete slab was poured over the top. The concrete slab was covered with soil and seeded with grass. Both the Site A and Plot M areas were decommissioned in 1956.

In 1973, elevated levels of hydrogen-3 (as tritiated water) were detected in two nearby handpumped picnic wells (\#5167 and \#5159) and the hydrogen-3 was found to be migrating from the burial plot into the surrounding soil and aquifers. As a result, a radiological survey of the entire Palos Forest Preserve site was conducted with special emphasis on the Site A and Plot M areas. ${ }^{1}$

In 1990, elevated levels of radioactivity were discovered outside the original fenced area. An expanded characterization and remediation program was conducted by DOE to remove residual radioactivity and document the remediation of the area. This was completed in 1997.

The terminology used in previous reports is continued in this report. A hole drilled and completed into the glacial drift is called a borehole. The soil samples obtained from the borehole are called soil cores. Some boreholes have been cased and screened to form monitoring wells. Water from such wells is called groundwater. Test wells drilled into the dolomite bedrock are called dolomite holes or deep holes. Water from such wells is called dolomite water. The hand-pumped picnic wells, which are completed into or close to the dolomite bedrock, are called water wells or picnic wells. They are identified by a location name or well number. Except for well \#5160, these were in existence before this radiological and hydrological study of the area was begun. 
The results of radioactivity measurements are expressed in this report in terms of picocuries per liter (pCi/L) and nanocuries per liter $(\mathrm{nCi} / \mathrm{L})$ for water samples. Radiation effective dose equivalent calculations are reported in units of millirem (mrem) or millirem per year (mrem/y). The use of the term dose throughout this report means effective dose equivalent. Other abbreviations of units are defined in the text.

\subsection{Site Characteristics}

Geologically, Plot M is constructed on a moraine upland which is dissected by two valleys, the Des Plaines River valley to the north and the Calumet Sag valley to the south. The upland is characterized by rolling terrain with poorly developed drainage. Streams are intermittent and drain internally or flow to one of the valleys. The area is underlain by glacial drift, dolomite, and other sedimentary rocks. The uppermost bedrock is Silurian dolomite, into which both the picnic wells and some of the monitoring wells are placed, as described in the text. The dolomite bedrock is about 200 feet thick. The overlying glacial drift has a thickness that ranges from 165 feet at Site A to zero at the Des Plaines River and Calumet Sag Canal, and some of the monitoring wells terminate in this layer. The depth to bedrock at Plot M is about 130 feet.

Hydrologically, the surface water consists of ponds and intermittent streams. When there is sufficient water, the intermittent stream that drains Plot M flows from the highest point near Site A, past Plot M, then continues near the Red Gate Woods well (Figure 1.2) and discharges into the Illinois and Michigan (I\&M) Canal. The groundwater in the glacial drift and dolomite forms two distinct flow systems. The flow in the drift is controlled principally by topography. The flow in the dolomite, which is recharged by groundwater from the glacial drift, is controlled by two discharge areas, the Des Plaines River to the north and the Calumet Sag Canal to the south. Water usage in the area is confined to the hand-pumped picnic wells. These wells are open to the dolomite and are principally used in the warmer seasons. 
The climate is that of the upper Mississippi valley, as moderated by Lake Michigan, and is characterized by cold winters and hot summers. Precipitation averages about 37 inches annually. The largest rainfalls occur between April and September. The average monthly temperature ranges from $21^{\circ} \mathrm{F}$ in January to $73^{\circ} \mathrm{F}$ in July. Approximately 8.9 million people reside within 50 miles of the site; the population within a five-mile radius is about 150,000. The only portion of the Palos Forest Preserve in the immediate area of Plot $\mathrm{M}$ and Site $\mathrm{A}$ that is developed for public use is the Red Gate Woods picnic area (Figure 1.2), although small numbers of individuals use the more remote areas of the Palos Forest Preserve. 


\subsection{SUMMARY}

The results of the ongoing environmental monitoring and surveillance program at the Palos Forest Preserve site for 2003 are presented in this report. Sample collection and analyses for radioactive substances were conducted on surface and subsurface water.

Surface water samples collected from the stream that flows around Plot M showed the same hydrogen-3 concentration pattern seen in the past. Concentrations were at the ambient level of less than $0.1 \mathrm{nCi} / \mathrm{L}$ upstream of the Plot, increased up to $4.1 \mathrm{nCi} / \mathrm{L}$ at the seep adjacent to the Plot, then decreased further downstream.

The hydrogen-3 concentrations in the borehole and dolomite hole water follow a pattern consistent with that observed in the past. The hydrogen-3 concentration was highest in those boreholes nearest Plot M and downgradient of the Plot. Water from five of 13 boreholes analyzed for strontium-90 contained concentrations greater than the detection limit of $0.25 \mathrm{pCi} / \mathrm{L}$. The elevated strontium-90 levels (up to $4.59 \mathrm{pCi} / \mathrm{L}$ ) found in some boreholes are probably from the Plot, since concentrations above $0.25 \mathrm{pCi} / \mathrm{L}$ have not been observed in the groundwater due to atmospheric fallout from previous nuclear weapons testing, and no other source is known. Strontium-90 is a relatively mobile radionuclide and its presence in the borehole water is not unexpected and is probably due to migration that occurred before the Plot was capped. The strontium-90 results are consistent with those measured in the past.

Sampling of the forest preserve picnic wells shown in Figure 1.2 continued. In July 1988, the Red Gate Woods North Well (\#5160) was installed as a replacement drinking water supply for the Red Gate Woods Well (\#5167). The maximum and average hydrogen-3 concentrations of well \#5160 were $1.78 \mathrm{nCi} / \mathrm{L}$ and $1.06 \mathrm{nCi} / \mathrm{L}$, respectively. The well opposite the entrance to Red Gate Woods (\#5159) had a maximum hydrogen-3 concentration of $1.49 \mathrm{nCi} / \mathrm{L}$ and an annual average concentration of $0.43 \mathrm{nCi} / \mathrm{L}$. The previous pattern of relatively higher hydrogen-3 concentrations in the winter and relatively lower concentrations (less than the detection limit of $0.1 \mathrm{nCi} / \mathrm{L}$ ) in the summer is not readily apparent for the wells due to the overall low measured hydrogen-3 
concentrations. For the calculation of annual averages, all data, as measured, were retained in the data base and used to compute the average.

If water equal to the Red Gate Woods North Well (\#5160) average concentration of $1.06 \mathrm{nCi} / \mathrm{L}$ was the sole source of water for an individual, the annual dose from hydrogen-3 would be 0.048 mrem using the DOE dose conversion factor. ${ }^{24}$ Consumption of one liter of this water would produce a dose of $7 \times 10^{-5}$ mrem. Although the U. S. Environmental Protection Agency (EPA) drinking water regulations ${ }^{25}$ are not applicable because the picnic wells do not meet the EPA definition of a public drinking water supply, this concentration is about 5\% of the EPA annual limit of $20 \mathrm{nCi} / \mathrm{L}$. Table 4.3 provides a relative comparison of this calculated dose to natural and other sources of radiation.

The results of this program show that the radioactivity remaining at Site A, Plot M, and the Red Gate Woods area does not endanger the health or safety of the public visiting the site or those living in the vicinity. The potential radiation doses are very low compared to the relevant standards. 


\subsection{MONITORING PROGRAM}

The monitoring program is designed to assess the elevated hydrogen-3 (as tritiated water) concentrations in some of the picnic wells in the Palos Forest Preserve. This is accomplished by analyzing water from wells, deep holes, boreholes, and surface streams in the area. Samples are collected with a frequency ranging from biweekly to annually, depending on past results and proximity to Plot M. During 2003, 212 samples were collected, 303 analyses were performed, and 160 field measurements were conducted. Over the past few years, the monitoring program has been reduced in scope to focus on areas that have residual radioactivity. For the most part, individual results are presented in the tables and compared to control, off-site, or upstream sample results. Where applicable, results are compared to the U. S. Department of Energy Radiation Protection Standard of $100 \mathrm{mrem} / \mathrm{y} .{ }^{24}$ The Site A/Plot M program follows the guidance for monitoring at DOE facilities. $^{26}$ Although it is recognized that Site A/Plot M is not a DOE facility, the same monitoring principles are applicable to this site.

The uncertainties associated with individual concentrations given in the tables are the statistical counting errors at the 95\% confidence level. Because of the amount of hydrogen-3 data presented on a few tables, the uncertainty values are not included. In such cases, the following uncertainties apply:

Concentration (nCi/L)

0.1-1.0

1-10

$>10$
Uncertainty (\% of Conc.)

$40-5 \%$

$5-1 \%$

$1 \%$

The sensitivity for the measurement of hydrogen-3 in water has been improved. The current detection limit is $0.1 \mathrm{nCi} / \mathrm{L}$. 


\subsection{Surface Water}

Three sets of water samples were collected during 2003 from the stream that flows around Plot $\mathrm{M}$, primarily during the spring when the ground was no longer frozen but saturated. The stream was dry during scheduled sampling in the summer and fall. The sampling locations are shown in Figure 3.1. Sample Location \#10 is 100 yards north of Location \#9 and sample Location \#11 is 200 yards north of Location \#9. The outfall into the I\&M Canal is approximately 600 yards north of Plot M. The samples were analyzed for hydrogen-3 and the results are shown in Table 3.1. The same concentration pattern in the water flowing around Plot $\mathrm{M}$ was observed this year as in the past. Concentrations were low upstream of the Plot, increased as the stream flowed past the Plot, where it received hydrogen-3 that leached out of the burial site, then decreased downstream due to dilution by precipitation. The outfall sample was collected prior to discharge into the I\&M Canal.

Using the methodology prescribed in the DOE guidance, ${ }^{24}$ the committed effective dose equivalent from consumption of water can be calculated. The total quantity of an ingested radionuclide is obtained by multiplying the water concentration by the general public water ingestion rate of $730 \mathrm{~L} / \mathrm{y} .{ }^{27}$ This annual intake is then multiplied by the 50 -year Committed Effective Dose Equivalent (CEDE) factor. ${ }^{28}$ The CEDE for hydrogen-3 in water is $6.3 \times 10^{-5}$ $\mathrm{rem} / \mu \mathrm{Ci}$. If a hypothetical individual used water with the same hydrogen-3 concentration as found in the seep (Location \#6) as his sole source of water, the annual dose based on the maximum 2003 concentration of $4.1 \mathrm{nCi} / \mathrm{L}$ would be about $0.2 \mathrm{mrem} / \mathrm{y}$ and the dose based on the annual average seep concentration of $2.7 \mathrm{nCi} / \mathrm{L}$ would be $0.1 \mathrm{mrem} / \mathrm{y}$. The DOE dose limit for the public is 100 $\mathrm{mrem} / \mathrm{y}$. Using the same calculations for concentrations at Location \#9, the maximum concentration of $1.3 \mathrm{nCi} / \mathrm{L}$ would produce $0.06 \mathrm{mrem} / \mathrm{y}$ and the 2003 average concentration of $0.8 \mathrm{nCi} / \mathrm{L}$ would give a dose of $0.04 \mathrm{mrem} / \mathrm{y}$. Consumption of one liter of water with the same annual average concentration as at Location \#9 would produce a dose of $0.00005 \mathrm{mrem} / \mathrm{y}$. In general, the hydrogen3 concentrations vary from year to year and are dependent on the amount of precipitation. 


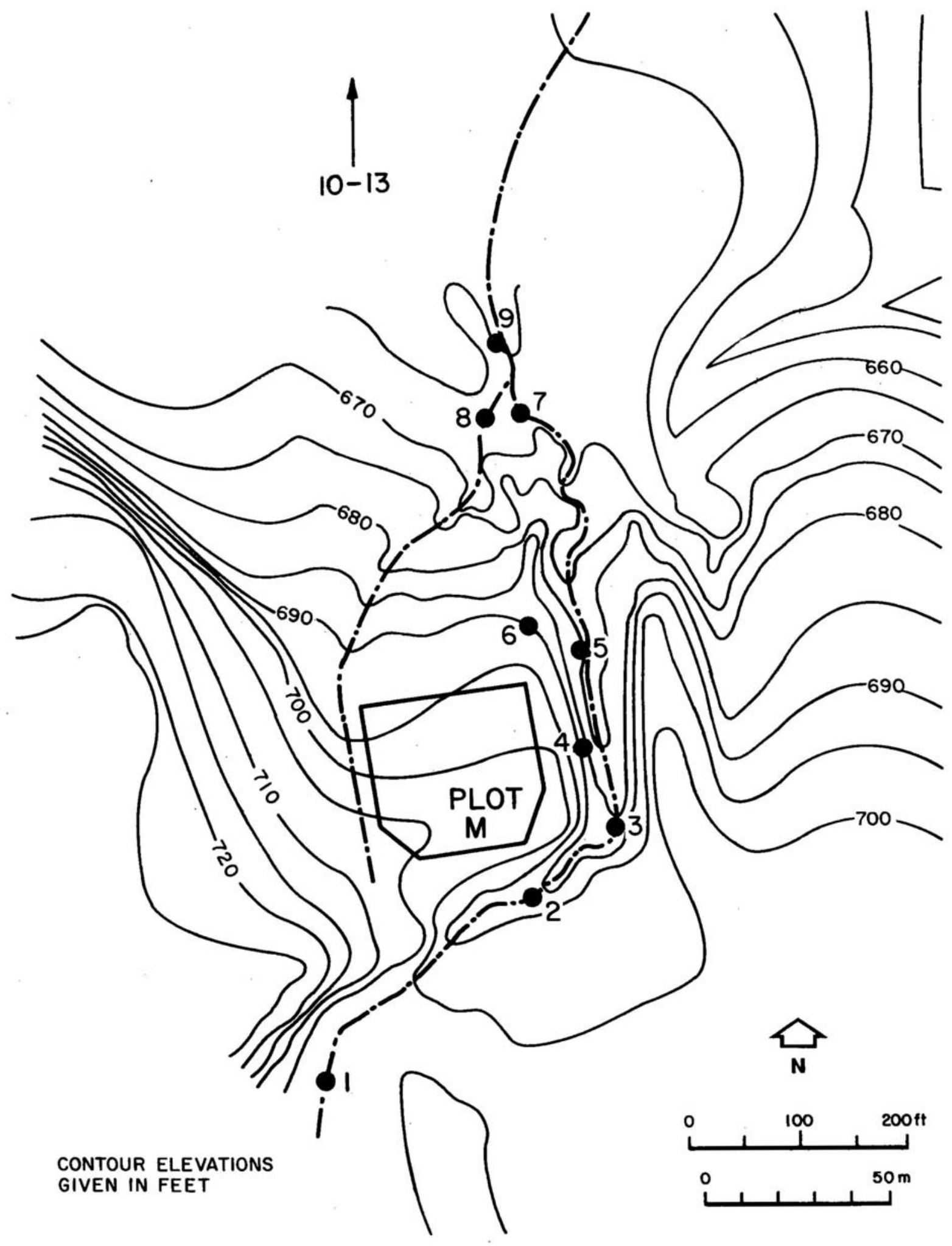

Figure 3.1 Surface Water Sampling Locations Near Plot M 


\section{Table 3.1}

Hydrogen-3 Content of Stream Next to Plot M, 2003

(Concentrations in $\mathrm{nCi} / \mathrm{L}$ )

\begin{tabular}{cccc}
\hline \multirow{2}{*}{$\begin{array}{c}\text { Location } \\
\text { Number* }\end{array}$} & Darch 13 & May 5 & November 18 \\
\cline { 2 - 4 } 1 & $<0.1$ & $<0.1$ & $<0.1$ \\
2 & $<0.1$ & $<0.1$ & $<0.1$ \\
3 & $<0.1$ & $<0.1$ & $<0.1$ \\
4 & $1.3 \pm 0.1$ & $1.4 \pm 0.1$ & $0.6 \pm 0.1$ \\
5 & $0.8 \pm 0.1$ & $1.4 \pm 0.1$ & $0.5 \pm 0.1$ \\
6 (Seep) & $<0.1$ & $4.1 \pm 0.1$ & $1.3 \pm 0.1$ \\
7 & $0.7 \pm 0.1$ & $1.3 \pm 0.1$ & $0.4 \pm 0.1$ \\
8 & $0.7 \pm 0.1$ & $0.6 \pm 0.1$ & $0.3 \pm 0.1$ \\
9 & $0.6 \pm 0.1$ & $1.3 \pm 0.1$ & $0.5 \pm 0.1$ \\
10 & $0.4 \pm 0.1$ & $1.1 \pm 0.1$ & $0.3 \pm 0.1$ \\
11 & $0.3 \pm 0.1$ & $1.0 \pm 0.1$ & $0.3 \pm 0.1$ \\
Outfall & $<0.1$ & $0.4 \pm 0.1$ & $0.2 \pm 0.1$ \\
\hline
\end{tabular}

* See Figure 3.1

** I \& M Canal 


\subsection{Subsurface Water}

\subsubsection{Borehole Water - Plot M}

A number of the boreholes drilled in the Plot $\mathrm{M}$ area (Figure 3.2) were cased with plastic pipe and screens were installed to serve as sampling points within the glacial drift. Water samples were collected and water level measurements were made in the Plot M boreholes approximately quarterly, weather permitting. Each borehole was emptied of water and allowed to recharge before sampling. The shallow boreholes responded to the spring precipitation as indicated by an increase in water levels followed by a drop during summer and fall when moisture was used for plant growth. The water levels in the deeper boreholes generally deeper than $100 \mathrm{ft}$, were relatively constant throughout the year. In July 2001, Boreholes 1, 11 (68 feet), 24, and 36 were closed in accordance with applicable State of Illinois regulations. The wells were closed because they were dry or not sealed properly and the remaining wells provide adequate coverage.

All the water samples were analyzed for hydrogen-3 and the results are collected in Table 3.2. The hydrogen-3 concentrations varied widely as in past years. The measured water levels in the boreholes are in Table 3.3. Since the measurement of the water levels is made relative to a benchmark at the top of the well casing, a decrease in numerical value indicates a rise in water level. Higher hydrogen-3 concentrations in borehole water correlate with higher hydrogen-3 concentration in split-spoon soil cores obtained when the boreholes were constructed. As supported by the water level measurements, the winter of 2003 was very dry resulting in a substantial drop in the water table. In general, the magnitude of the hydrogen-3 concentrations are similar to those observed over the past several years. 


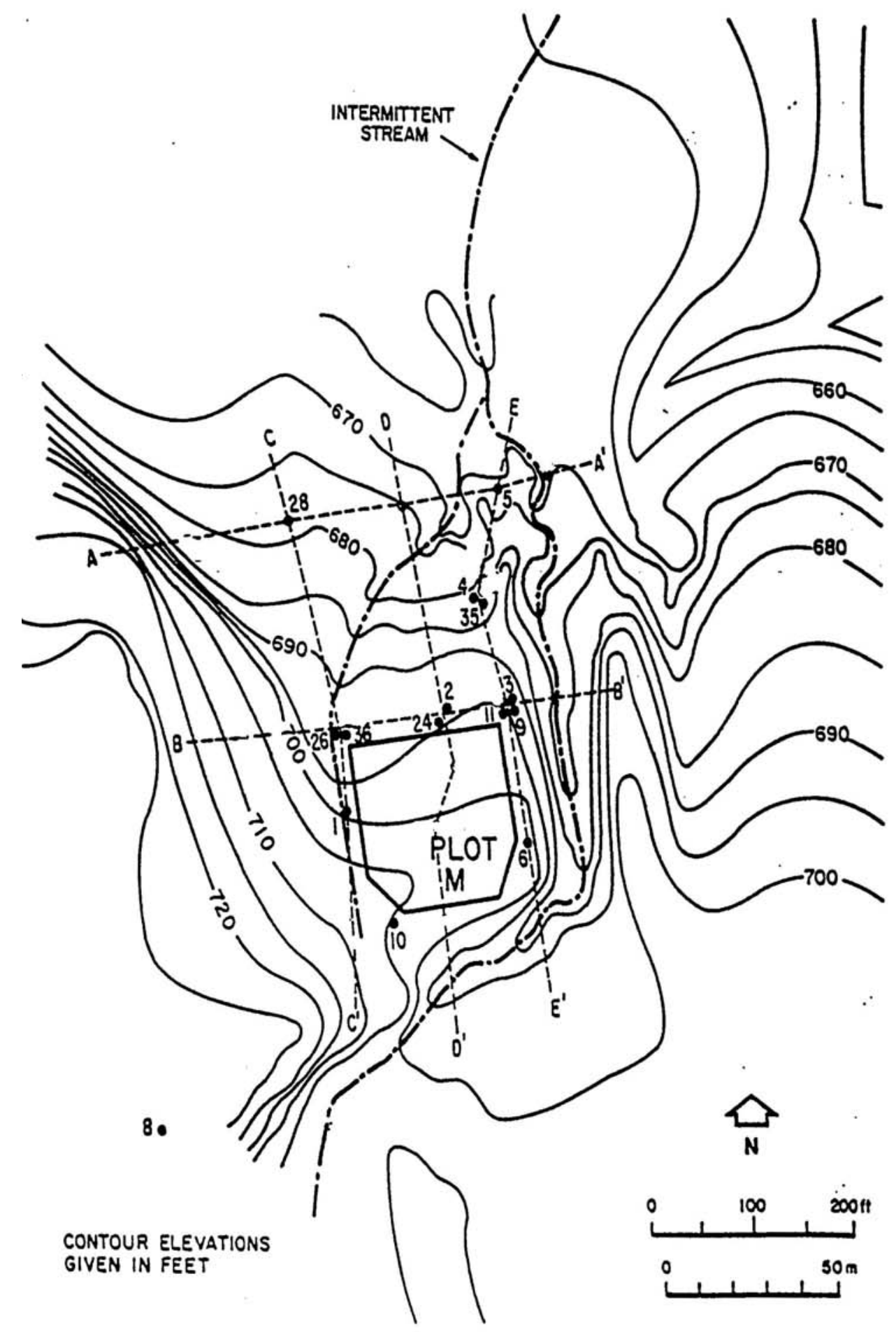

Figure 3.2 Map of Plot M Palos Site Showing Topography, Intermittent Stream, and Borehole Locations 
Table 3.2

Hydrogen-3 in Plot M Borehole Water, 2003

(Concentrations in $\mathrm{nCi} / \mathrm{L}$ )

\begin{tabular}{cccccc}
\hline \multirow{2}{*}{$\begin{array}{c}\text { Borehole } \\
\text { Number }\end{array}$} & $\begin{array}{c}\text { Depth } \\
(\mathrm{ft})\end{array}$ & February 26 & May 20 & Date Collected \\
\cline { 3 - 6 } & 39.41 & 3385.0 & 5.0 & 10.8 & Dugust 5 \\
3 & 40.00 & 1013.0 & 1050.0 & 892.4 & 5.5 \\
4 & 36.05 & 636.8 & 640.8 & 719.1 & 810.5 \\
5 & 40.20 & 60.0 & 58.1 & 58.3 & 644.4 \\
6 & 40.30 & 70.4 & 61.7 & 62.7 & 59.4 \\
8 & 40.00 & $<0.1$ & 0.5 & $<0.1$ & 65.7 \\
9 & $40.00^{*}$ & DRY & DRY & DRY & 0.3 \\
10 & $40.00^{*}$ & DRY & 62.7 & 269.6 & 457.7 \\
11 & 39.30 & 234.0 & 112.4 & 167.6 & 85.2 \\
11 & 121.90 & 52.6 & 25.6 & 17.2 & 27.8 \\
26 & 60.65 & 455.0 & 163.5 & 374.5 & 22.5 \\
28 & 58.25 & 445.7 & 62.4 & 51.2 & 338.1 \\
35 & 105.50 & 61.3 & 301.9 & 436.7 & 53.7 \\
\hline
\end{tabular}

* Slant hole drilled at $45^{\circ}$ to a depth of $40 \mathrm{ft}$ below the surface. 

TABLE 3.3

Water Level Measurements in Boreholes Near Plot M, 2003

(Units of feet below the benchmark at the top of the well)

\begin{tabular}{|c|c|c|c|c|c|}
\hline \multirow[b]{2}{*}{$\begin{array}{l}\text { Borehole } \\
\text { Number }\end{array}$} & \multicolumn{5}{|c|}{ Date Measured } \\
\hline & $\begin{array}{l}\begin{array}{c}\text { Depth } \\
\text { (ft) }\end{array}\end{array}$ & February 26 & May 20 & August 5 & December 11 \\
\hline 2 & 39.41 & 36.62 & 27.28 & 28.73 & 24.67 \\
\hline 3 & 40.00 & 39.21 & 40.11 & 37.90 & 37.14 \\
\hline 4 & 36.05 & 29.46 & 23.97 & 22.23 & 20.84 \\
\hline 5 & 40.20 & 35.02 & 31.55 & 27.31 & 30.54 \\
\hline 6 & 40.30 & 40.02 & 38.26 & 36.89 & 35.98 \\
\hline 8 & 40.00 & 39.17 & 35.68 & 36.48 & 34.55 \\
\hline 11 & 39.30 & 36.43 & 24.04 & 28.04 & 20.93 \\
\hline 11 & 121.90 & 106.52 & 106.66 & 106.42 & 106.35 \\
\hline 26 & 60.65 & 57.18 & 54.27 & 53.36 & 53.58 \\
\hline 28 & 58.25 & 51.69 & 57.49 & 55.00 & 53.75 \\
\hline 35 & 105.50 & 94.18 & 94.21 & 94.03 & 93.88 \\
\hline
\end{tabular}



The EPA protocols suggest that a monitoring well be purged and a sample collected within the first two hours or the sample may not be representative of the groundwater. Geological conditions at Plot M make it very difficult to follow the EPA guidance. Many of the monitoring wells at Plot M have been placed in clay-rich units with very low permeability. Recharge to these monitoring wells over a two-hour period is insufficient to obtain an appropriate volume (up to one gallon) of water to conduct the analytical tests. The EPA criteria applies to situations where sensitive constituents such as volatile organic chemicals are of concern. Groundwater analyses at Plot M are for radioactive constituents, especially hydrogen-3 which is less sensitive to chemical or physical loss from the groundwater than the volatile organic chemicals. However, the EPA sampling protocol was applied for samples collected during 2003, where operationally feasible.

As part of a search for radionuclides other than hydrogen-3 in the borehole monitoring wells, sets of large volume water samples were collected to obtain greater sensitivity in the analysis. One set of samples was collected on May 20, 2003, and another set was collected December 11, 2003. Samples were collected from all boreholes that yielded sufficient water for analysis. The samples were analyzed for strontium-90 and the results are shown in Table 3.4. Strontium-90 concentrations greater than the detection limit of $0.25 \mathrm{pCi} / \mathrm{L}$ were found in five of the 13 sampled boreholes. Levels above $0.25 \mathrm{pCi} / \mathrm{L}$ would not be expected in this water from fallout, and no other source is known. The highest strontium-90 concentration in 2003 was 4.59 pCi/L in water from Borehole \#9. The results are less than the State of Illinois Class 1 Ground Water Quality Standard value of 8 pCi/L. Historically, the highest concentration was found in 1991, 10.7 pCi/L in Borehole \#11 (68 feet). In the past, Borehole \#6, which is between the buried waste and the stream that flows around Plot $\mathrm{M}$, showed measurable strontium-90 concentrations. The data suggest that small but measurable amounts of strontium-90 have migrated from the waste into the surrounding glacial drift. 


\section{Table 3.4}

Strontium-90 Content of Borehole Water Samples Near Plot M, 2003 (Concentrations in $\mathrm{pCi} / \mathrm{L}$ )

\begin{tabular}{|c|c|c|c|}
\hline $\begin{array}{l}\text { Borehole } \\
\text { Number* }\end{array}$ & $\begin{array}{l}\text { Depth } \\
(\mathrm{ft})\end{array}$ & $\begin{array}{l}\text { Date } \\
\text { Collected }\end{array}$ & Strontium-90 \\
\hline 2 & 39.41 & $\begin{array}{l}\text { May } 20 \\
\text { December } 11\end{array}$ & $\begin{array}{l}<0.25 \\
<0.25\end{array}$ \\
\hline 3 & 40.00 & $\begin{array}{l}\text { May } 20 \\
\text { December } 11\end{array}$ & $\begin{array}{l}\text { DRY } \\
<0.25\end{array}$ \\
\hline 4 & 36.05 & $\begin{array}{l}\text { May } 20 \\
\text { December } 11\end{array}$ & $\begin{array}{l}<0.25 \\
<0.25\end{array}$ \\
\hline 5 & 40.20 & $\begin{array}{l}\text { May } 20 \\
\text { December } 11\end{array}$ & $\begin{array}{l}<0.25 \\
<0.25\end{array}$ \\
\hline 6 & 40.30 & $\begin{array}{l}\text { May } 20 \\
\text { December } 11\end{array}$ & $\begin{array}{l}1.00 \pm 0.10 \\
0.51 \pm 0.05\end{array}$ \\
\hline 8 & 40.00 & $\begin{array}{l}\text { May } 20 \\
\text { December } 11\end{array}$ & $\begin{array}{l}<0.25 \\
<0.25\end{array}$ \\
\hline 9 & $40.00 * *$ & $\begin{array}{l}\text { May } 20 \\
\text { December } 11\end{array}$ & $\begin{array}{c}\text { DRY } \\
4.59 \pm 0.44\end{array}$ \\
\hline 10 & $40.00 * *$ & $\begin{array}{l}\text { May } 20 \\
\text { December } 11\end{array}$ & $\begin{array}{l}0.42 \pm 0.03 \\
\quad<0.25\end{array}$ \\
\hline 11 & 39.30 & $\begin{array}{l}\text { May } 20 \\
\text { December } 11\end{array}$ & $\begin{array}{l}2.99 \pm 0.27 \\
\quad<0.25\end{array}$ \\
\hline 11 & 121.90 & $\begin{array}{l}\text { May } 20 \\
\text { December } 11\end{array}$ & $\begin{array}{l}<0.25 \\
<0.25\end{array}$ \\
\hline 26 & 60.65 & $\begin{array}{l}\text { May } 20 \\
\text { December } 11\end{array}$ & $\begin{array}{c}0.65 \pm 0.06 \\
<0.25\end{array}$ \\
\hline 28 & 58.25 & $\begin{array}{l}\text { May } 20 \\
\text { December } 11\end{array}$ & $\begin{array}{l}\text { DRY } \\
<0.25\end{array}$ \\
\hline 35 & 105.50 & $\begin{array}{l}\text { May } 20 \\
\text { December } 11\end{array}$ & $\begin{array}{l}<0.25 \\
<0.25\end{array}$ \\
\hline
\end{tabular}

* See Figure 3.2

** Slant hole 


\subsubsection{Borehole Water - Site A}

In late 1993, four boreholes (BH-41, BH-42, BH-43, and BH-44), were installed at Site A (see Figure 3.3) to improve Site A perimeter monitoring. In 1994, 12 monitoring wells were constructed at Site A to support the expanded characterization of this area. With the characterization study completed in the spring of 1995, the wells were transferred to the monitoring program for continued use as part of the surveillance network. These wells are also shown in Figure 3.3. Although still shown in the figure, the fence was removed in April 1998. Dedicated pumps and associated equipment were installed in July of 1995. In July 2002, Borehole \#43 was closed because it was continually dry. The samples are collected semi-annually and analyzed for hydrogen-3, strontium 90, and gamma-ray emitters.

Hydrogen-3 results for all the Site A boreholes are shown in Table 3.5. Water levels were also measured in these boreholes and these measurement results appear in Table 3.6. The hydrogen-3 concentrations were all low, but the pattern throughout the year was consistent. The elevated hydrogen-3 levels in Borehole \#41 is probably from the site landfill, while the hydrogen-3 in Borehole \#55 and Borehole \#56 most likely is from the CP-3 buried biological shield. The results of the strontium-90 analyses are shown in Table 3.7. The elevated strontium-90 results appear to track with elevated hydrogen-3 results. For example, Boreholes \#55 and \#56 had measurable levels of hydrogen-3 and strontium-90 throughout the year. All gamma-ray emitters were below the detection limit of $1 \mathrm{pCi} / \mathrm{L}$.

\subsubsection{Dolomite Hole Water}

At the present time, 14 wells are cased into the dolomite zone to monitor the movement of any radionuclides in this aquifer. Most of the dolomite holes are located north of Plot $\mathrm{M}$ and east of the Red Gate Woods North Well (\#5160), as shown in Figure 1.2 


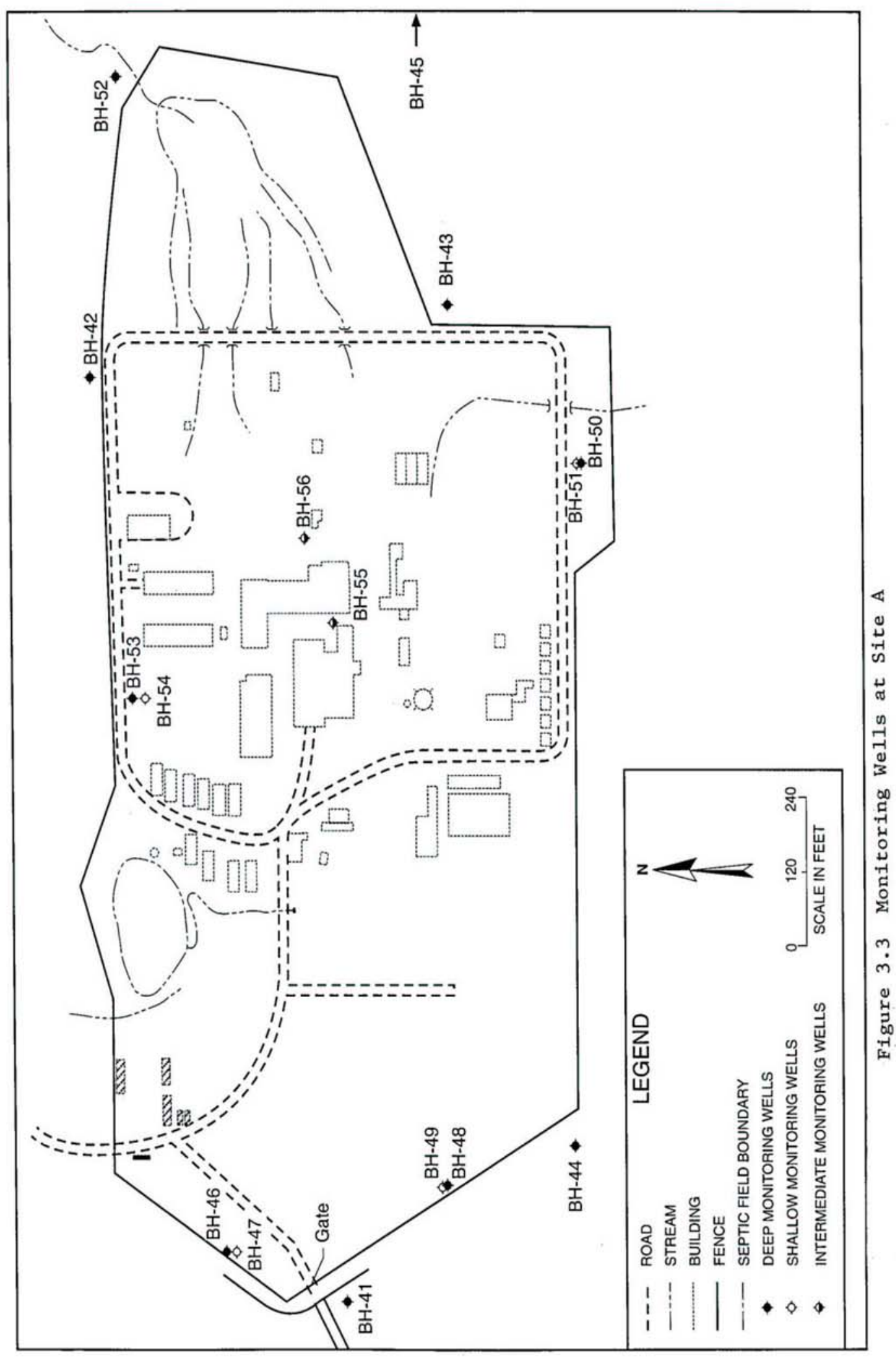




\section{Table 3.5}

Hydrogen-3 in Site A Borehole Water, 2003

(Concentrations in $\mathrm{nCi} / \mathrm{L}$ )

\begin{tabular}{crrr}
\hline & & \multicolumn{2}{c}{ Date Collected } \\
Borehole & $\begin{array}{c}\text { Depth } \\
\text { Number }\end{array}$ & June 5 & August 26 \\
\cline { 3 - 4 } 41 & 25.83 & 0.1 & 0.3 \\
42 & 53.01 & $<0.1$ & $<0.1$ \\
44 & 31.02 & $<0.1$ & $<0.1$ \\
45 & 166.50 & $<0.1$ & $<0.1$ \\
46 & 190.80 & $<0.1$ & $<0.1$ \\
47 & 44.30 & 0.1 & $<0.1$ \\
48 & 192.20 & $<0.1$ & $<0.1$ \\
49 & 45.60 & $<0.1$ & $<0.1$ \\
50 & 162.80 & $<0.1$ & $<.1$ \\
51 & 116.40 & $<0.1$ & $<0.1$ \\
52 & 165.00 & $<0.1$ & $<0.1$ \\
53 & 177.30 & $<0.1$ & 0.1 \\
54 & 63.40 & 0.2 & DRY \\
55 & 87.20 & 6.6 & 3.9 \\
56 & 102.40 & 3.9 & 0.1 \\
\hline & & & $<$ \\
\hline
\end{tabular}




\section{TABLE 3.6}

Water Level Measurements in Boreholes Near Site A, 2003

(Units in feet below the benchmark at the top of the well)

\begin{tabular}{ccrc}
\hline & & \multicolumn{2}{c}{ Date Measured } \\
\cline { 3 - 4 } $\begin{array}{c}\text { Borehole } \\
\text { Number }\end{array}$ & $\begin{array}{c}\text { Depth to } \\
\text { Bottom }(\mathrm{ft})\end{array}$ & June 5 & August 26 \\
\hline 41 & 25.83 & 9.33 & 12.87 \\
42 & 53.01 & 50.05 & 45.28 \\
44 & 31.02 & 10.55 & 14.96 \\
45 & 166.50 & 142.50 & 143.45 \\
46 & 190.80 & 156.65 & 157.62 \\
47 & 44.30 & 16.44 & 18.14 \\
48 & 192.20 & 159.10 & 159.98 \\
49 & 45.60 & 17.23 & 18.33 \\
50 & 162.80 & 108.27 & 108.40 \\
51 & 116.40 & 102.70 & 102.88 \\
52 & 165.00 & 131.89 & 132.62 \\
53 & 177.30 & 149.74 & 150.48 \\
54 & 63.40 & 57.10 & 56.72 \\
55 & 87.20 & 85.46 & DRY \\
56 & 102.40 & 88.57 & 88.85 \\
\hline
\end{tabular}




\section{Table 3.7}

Strontium-90 of Borehole Water Samples Near Site A, 2003

(Concentrations in $\mathrm{pCi} / \mathrm{L}$ )

\begin{tabular}{cccc}
\hline & & \multicolumn{2}{c}{ Date Collected } \\
\cline { 3 - 4 } $\begin{array}{c}\text { Berehole } \\
\text { Number }\end{array}$ & $(\mathrm{ft})$ & June 5 & August 26 \\
\hline 41 & 25.83 & $<0.25$ & $<0.25$ \\
42 & 53.01 & $<0.25$ & $<0.25$ \\
44 & 31.02 & $<0.25$ & $<0.25$ \\
45 & 166.50 & $<0.25$ & $<0.25$ \\
46 & 190.80 & $<0.25$ & $<0.25$ \\
47 & 44.30 & $<0.25$ & $<0.25$ \\
48 & 192.20 & $<0.25$ & $<0.25$ \\
49 & 45.60 & $<0.25$ & $<0.25$ \\
50 & 162.80 & $<0.25$ & $<0.25$ \\
51 & 116.40 & $<0.25$ & $<0.25$ \\
52 & 165.00 & $<0.25$ & $<0.25$ \\
53 & 177.30 & $<0.25$ & $<0.25$ \\
54 & 63.40 & $<0.25$ & $<0.25$ \\
55 & 87.20 & $13.14 \pm 1.03$ & $2.82 \pm 0.23$ \\
56 & 102.40 & $2.97 \pm 0.24$ &
\end{tabular}


and/or Figure 3.4. Water was normally collected from the dolomite holes twice per year. All samples were analyzed for hydrogen-3 and the results are in Table 3.8. Water levels were also measured in the dolomite holes and these measurements are in Table 3.9.

In December 1993, DH 11 through DH 14 were grouted with cement to $535 \mathrm{ft}$ MSL. The purpose of the grouting was to seal off the lower dolomite fractures that are connected to the handpumped picnic wells in the Red Gate Woods area. It is speculated that these lower fractures allow elevated levels of hydrogen-3 in the dolomite holes to migrate to the picnic well. In addition, covers to three of the dolomite holes were repaired.

In September 1994, three of the dolomite holes, DH 6, DH 7, and DH 8, were abandoned because the wells were not sealed into the dolomite, but were open to the glacial drift. As such, they were not sampling dolomite water. Borehole \#40 was also abandoned at the same time because the well casing was probably compromised. In accordance with well sealing procedures established by the Illinois Environmental Protection Agency, the casing was filled with clean gravel and sand, sealed with bentonite, the casing removed to three feet below the ground level, and backfilled with clean soil. In July 2001, DH 16 was closed because of an obstruction in the pipe that prevented sampling

The results of the hydrogen-3 analyses of the dolomite holes are consistent with concentrations measured in the past. Ten of the dolomite holes had measurable hydrogen-3 concentrations. The highest hydrogen-3 levels are in the eight dolomite holes, DH 9 to DH 15 and DH 17, which are the furthest north and near the surface stream that flows next to Plot M (see Section 3.2). The distribution of hydrogen-3 in these wells supports the USGS interpretation ${ }^{29}$ that a large hydrogen-3 plume underlies the stream. The plume has spread downward as well as downgradient resulting in the current configuration of the hydrogen-3 concentrations in the dolomite. The other dolomite hole with elevated hydrogen-3 is DH 3, which is immediately downgradient from Plot M. Previous analyses of soil core samples indicated the presence of hydrogen-3 down to the drift-dolomite interface at DH 3. 


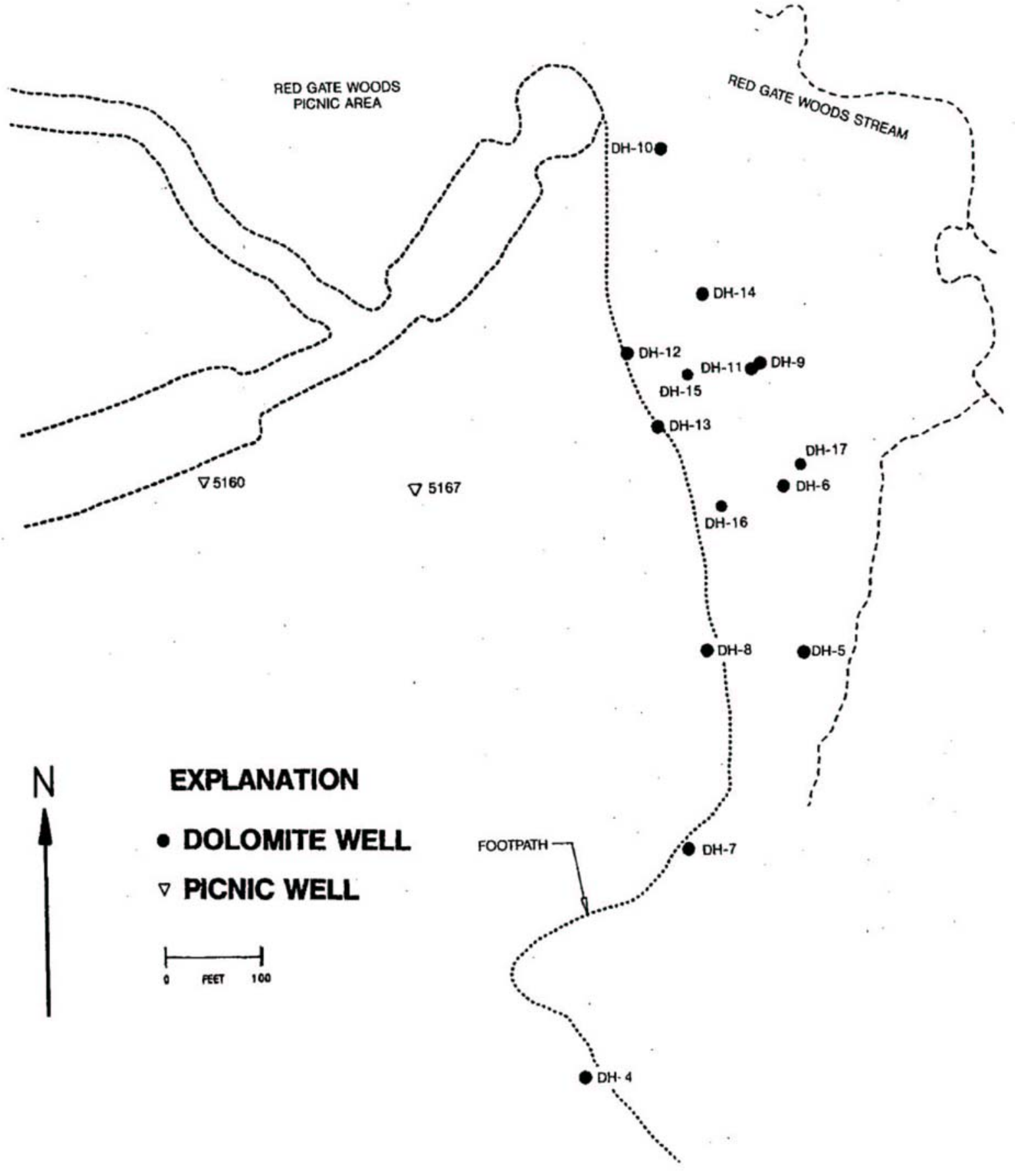

Figure 3.4 Locations of Dolomite Holes North of Plot M 


\section{Table 3.8}

Hydrogen-3 in Dolomite Holes, 2003

(Concentrations in $\mathrm{nCi} / \mathrm{L}$ )

\begin{tabular}{|c|c|c|}
\hline \multirow{2}{*}{$\begin{array}{c}\text { Dolomite } \\
\text { Hole } \\
\text { Number }\end{array}$} & \multicolumn{2}{|c|}{ Date Collected } \\
\hline & May 22 & November 26 \\
\hline 1 & $<0.1$ & $<0.1$ \\
\hline 2 & $<0.1$ & 0.1 \\
\hline 3 & 1.5 & 1.5 \\
\hline 4 & 0.1 & 0.8 \\
\hline 5 & $<0.1$ & $<0.1$ \\
\hline 9 & 0.6 & 0.9 \\
\hline 10 & 1.7 & 0.6 \\
\hline 11 & 2.0 & 2.1 \\
\hline 12 & 2.8 & 0.9 \\
\hline 13 & 1.7 & 0.4 \\
\hline 14 & 0.7 & 2.3 \\
\hline 15 & 2.0 & 1.6 \\
\hline 17 & 0.3 & 0.5 \\
\hline 18 & $<0.1$ & $<0.1$ \\
\hline
\end{tabular}




\section{TABLE 3.9}

Water Level Measurements in Dolomite Holes 2003

(Units in feet below the benchmark at the top of the well)

\begin{tabular}{ccc}
\hline $\begin{array}{c}\text { Dolomite } \\
\text { Hole } \\
\text { Number }\end{array}$ & \multicolumn{2}{c}{ Date Measured } \\
\cline { 2 - 3 } 2 & May 22 & November 26 \\
\hline 3 & 161.32 & 162.10 \\
4 & 979.47 & 140.17 \\
5 & 93.15 & 98.71 \\
9 & 78.18 & 93.89 \\
10 & 73.26 & 78.93 \\
11 & 63.93 & 73.36 \\
12 & 75.61 & 62.72 \\
13 & 76.79 & 75.82 \\
14 & 77.65 & 76.95 \\
15 & 71.80 & 78.47 \\
17 & 79.42 & 71.99 \\
18 & 74.63 & 80.96 \\
\hline
\end{tabular}


Past sampling practices indicate different hydrogen-3 results are obtained depending on sampling methods. Within the dolomite hole wells north of Plot $\mathrm{M}$, collection of the sample near the top of the water column (shallow) will result in measurable hydrogen-3 concentrations. Sampling at the bottom of the water column (deep) will result in very low or non-detectable hydrogen-3 concentrations. In addition, samples collected at any depth after purging, removing up to $700 \mathrm{~L}$ of water before sampling, will result in samples with hydrogen-3 concentrations that are very low or non-detectable.

The explanation for the differences in hydrogen-3 concentration is that the hydrogen-3 is moving horizontally in the uppermost fractures of the dolomite. The hydrogen-3 is in a narrow band of the water column in the dolomite hole. Where a sample is collected with a bailer at the top of the water column, this hydrogen-3 zone is the area sampled resulting in measurable levels of hydrogen-3 in the sample. However, when the dolomite hole is purged, the volume of recharge water from other fractures that are free of hydrogen- 3 is such that the hydrogen- 3 concentration in the sample is generally at the detection limit. If the next quarter sample is collected without purging, the hydrogen-3 concentration is at the same level as earlier samples indicating that the fracture flow rapidly reached an equilibrium condition.

\subsubsection{Well Water}

In July 1988, a well was installed in the Red Gate Woods picnic area (\#5160) to replace the existing well (\#5167) as a drinking water supply for visitors to this area. This is referred to as the Red Gate Woods North Well (\#5160). This well was to be cased 20 feet into the dolomite to seal off fractures assumed to contain hydrogen-3. Previous experiments had indicated that the hydrogen-3 moved at the drift-dolomite interface and in the uppermost fractures in the dolomite. Extending the casing 20 feet into the dolomite and cementing the void between the casing and dolomite was expected to prevent hydrogen-3 from entering the new well via these fractures. But this was not successful. In addition, placement of a new pump mechanism on the new well was expected to eliminate the elevated lead concentrations found occasionally in the old well that resulted from corrosion of the old pump mechanism. The pump mechanism was removed from the old Red Gate Woods well to prevent its use by the public; however, the well was maintained as a sampling 
location for this monitoring program. In addition, the lower portion of the Red Gate Woods Well (\#5167) was filled with grout to seal the lower fractures and prevent communication of water with the new well. Since 1989, iron, lead, manganese, and zinc have regularly exceeded the GWQS at the Red Gate Woods North Well (\#5160).

Sampling was conducted throughout the year at the forest preserve picnic wells located north of Plot $\mathrm{M}$ and shown in Figure 1.2. All the samples were analyzed for hydrogen-3 and the results are listed in Table 3.10. Well \#5215 (Guard Post) became inoperative early in 1999, was not repairable, and was removed from the monitoring program. In addition, the Red Gate Woods North Well (\#5160) has not been available to the public since 1999 because of high fecal coliform levels. The hydrogen-3 concentrations in the wells have decreased to the level where the earlier pattern of high concentrations in the winter and low concentrations in the summer is not readily detectable. The maximum and average hydrogen-3 concentrations since 1976 for wells \#5160, \#5167, and \#5159 are presented in Table 3.11. The hydrogen-3 concentration over the past few years is illustrated in Figure 3.5, which is a plot of the hydrogen-3 concentrations in wells \#5160 and \#5159. The hydrogen-3 concentration in the Red Gate Woods North Well (\#5160) increased to about $2.2 \mathrm{nCi} / \mathrm{L}$ in November 1995 and has shown a gradual decrease in concentration during 1996, 1997, and 1998, remained constant throughout all of 1999, but gradually increased in 2000 and 2001. In mid-June 2002, the hydrogen-3 concentration in well \#5160 decreased by a factor of two, declined slowly for the rest of the year, but increased again in the spring of 2003. This sudden change was unanticipated since none of the upgradient wells showed any dramatic changes in hydrogen-3 concentrations. 
Table 3.10

Hydrogen-3 Content of Wells Near Site A/Plot M, 2003

(Concentrations in $\mathrm{nCi} / \mathrm{L}$ )

\begin{tabular}{|c|c|c|c|}
\hline $\begin{array}{l}\text { Date } \\
\text { Collected }\end{array}$ & $\begin{array}{c}\text { Red Gate } \\
\text { North } \\
5160 \\
\end{array}$ & $\begin{array}{c}\text { Opposite } \\
\text { Red Gate } \\
5159 \\
\end{array}$ & $\begin{array}{c}300 \text { yds. East } \\
\text { Red Gate } \\
5158\end{array}$ \\
\hline January 8 & 0.68 & 1.49 & 0.14 \\
\hline January 22 & 0.65 & 1.19 & - \\
\hline February 5 & 0.73 & 0.96 & 0.13 \\
\hline February 19 & 0.74 & 0.91 & - \\
\hline March 5 & 0.77 & 0.84 & 0.14 \\
\hline March 19 & 0.69 & 0.47 & - \\
\hline April 2 & 0.74 & 0.39 & 0.12 \\
\hline April 16 & 1.78 & 0.17 & - \\
\hline May 7 & 1.45 & 0.21 & 0.10 \\
\hline May 21 & 1.21 & 0.15 & - \\
\hline June 4 & 1.16 & 0.35 & 0.12 \\
\hline June 18 & 1.19 & 0.28 & - \\
\hline July 2 & 1.13 & 0.36 & 0.15 \\
\hline July 16 & 1.20 & 0.31 & - \\
\hline August 6 & 0.99 & 0.19 & $<0.10$ \\
\hline August 20 & 1.19 & 0.23 & - \\
\hline September 3 & 1.13 & $<0.10$ & $<0.10$ \\
\hline September 17 & 1.26 & 0.18 & - \\
\hline October 1 & 1.11 & 0.10 & $<0.10$ \\
\hline October 15 & 1.21 & 0.19 & - \\
\hline November 5 & 1.21 & 0.23 & 0.17 \\
\hline November 19 & 1.12 & 0.36 & - \\
\hline December 3 & 1.08 & 0.33 & 0.15 \\
\hline December 17 & 1.10 & 0.33 & - \\
\hline Average & 1.06 & 0.43 & 0.12 \\
\hline
\end{tabular}


TABLE 3.11

Annual Maximum and Average Hydrogen-3 Concentrations in the Red Gate Woods Wells

(Concentrations in $\mathrm{nCi} / \mathrm{L}$ )

\begin{tabular}{|c|c|c|c|c|c|c|}
\hline \multirow{3}{*}{$\begin{array}{l}\text { Year } \\
1976\end{array}$} & \multicolumn{2}{|c|}{ Red Gate Woods North (\#5160) } & \multicolumn{2}{|c|}{ Red Gate Woods (\#5167) } & \multicolumn{2}{|c|}{$\begin{array}{l}\text { Opposite Red Gate Woods } \\
\text { (\#5159) }\end{array}$} \\
\hline & Maximum & & Maximum & & Maximum & Annual Average \\
\hline & & & 11.0 & 6.1 & 4.4 & 1.90 \\
\hline 1977 & & & 9.2 & 8.2 & 5.1 & 2.10 \\
\hline 1978 & & & 12.2 & 7.5 & 2.4 & 1.30 \\
\hline 1979 & & & 11.4 & 7.1 & 2.6 & 0.96 \\
\hline 1980 & & & 8.8 & 7.0 & 1.6 & 1.02 \\
\hline 1981 & & & 9.6 & 4.3 & 2.1 & 1.06 \\
\hline 1982 & & & 11.0 & 4.8 & 3.2 & 0.79 \\
\hline 1983 & & & 5.1 & 2.2 & 1.8 & 0.95 \\
\hline 1984 & & & 2.7 & 1.2 & 1.70 & 0.70 \\
\hline 1985 & & & 2.5 & 1.0 & 1.60 & 0.69 \\
\hline 1986 & & & 3.4 & 1.3 & 0.94 & 0.60 \\
\hline 1987 & & & 3.3 & 1.6 & 0.73 & 0.54 \\
\hline 1988 & 0.30 & 0.19 & 0.48 & 0.18 & 1.91 & $1.32^{\circ}$ \\
\hline 1989 & 0.41 & 0.27 & 0.46 & 0.30 & 0.92 & 0.61 \\
\hline 1990 & 0.52 & 0.22 & 0.25 & 0.12 & 2.07 & 1.14 \\
\hline 1991 & 0.80 & 0.35 & 0.21 & $<0.1$ & 2.26 & 1.43 \\
\hline 1992 & 0.54 & 0.25 & 0.13 & $<0.1$ & 2.29 & 1.15 \\
\hline 1993 & 0.57 & 0.23 & $<0.1$ & $<0.1$ & 1.63 & 0.87 \\
\hline 1994 & 0.40 & 0.31 & $<0.1$ & $<0.1$ & 0.46 & 0.30 \\
\hline 1995 & 2.26 & 0.51 & $<0.1$ & $<0.1$ & 0.54 & 0.40 \\
\hline 1996 & 2.19 & 1.56 & Closed/Sealed N & & 0.55 & 0.33 \\
\hline 1997 & 1.26 & 1.00 & & & 1.13 & 0.35 \\
\hline 1998 & 1.23 & 1.03 & & & 0.72 & 0.47 \\
\hline 1999 & 1.22 & 1.07 & & & 2.14 & 0.45 \\
\hline 2000 & 1.54 & 1.33 & & & 2.20 & 0.70 \\
\hline 2001 & 1.59 & 1.49 & & & 0.27 & 0.16 \\
\hline 2002 & 1.47 & 1.04 & & & 3.17 & 0.45 \\
\hline 2003 & 1.78 & 1.06 & & & 1.49 & 0.43 \\
\hline
\end{tabular}

*The replacement well (\#5160) was installed in July 1988. 


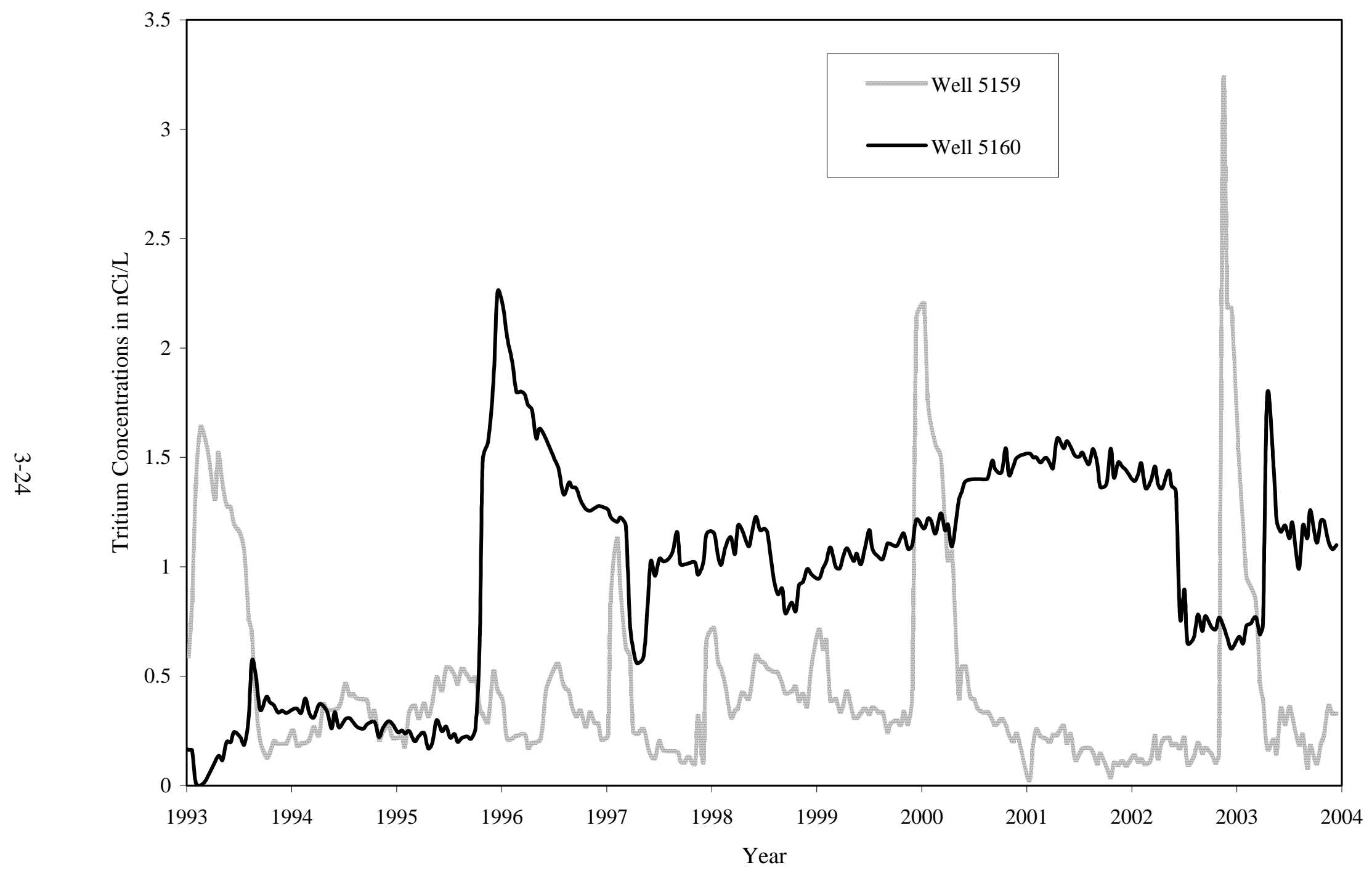

Figure 3.5 Hydrogen-3 Concentrations in Opposite Red Gate Woods (\#5159), and Red Gate Woods North (\#5160) Wells From 1993 Through 2003 
Before the Red Gate Woods Well (\#5167) was sealed, the hydrogen-3 concentrations had decreased to below the detection limit. The hydrogen-3 concentrations in the well opposite Red Gate Woods (\#5159) are more irregular and may be related to the amount of precipitation. The hydrogen-3 concentrations increased by almost a factor of ten in mid-November 2002 and then decreased to the prior levels by March 2003 and remained at about $0.3 \mathrm{nCi} / \mathrm{L}$ for the rest of the year. This pattern occurred before, in early 1996, to a lesser degree in early 1997 and early 1998, and more pronounced in early 1999. The hydrogen-3 concentrations in Well \#5167 has been very steady, ranging from $1.0 \mathrm{nCi} / \mathrm{L}$ to $1.5 \mathrm{nCi} / \mathrm{L}$ over the past several years. The exception being a decrease to about $0.7 \mathrm{nCi} / \mathrm{L}$ in June 2002 through April 2003. In mid-April 2003 the concentrations returned to their previous levels (See Figure 3.5)

If water equal to the Red Gate Woods North well average concentration of $1.06 \mathrm{nCi} / \mathrm{L}$ was the sole source of water for an individual, the annual dose from the hydrogen-3 would be $0.048 \mathrm{mrem}$. If an individual consumed one liter of this water, the dose would be $7 \times 10^{-5} \mathrm{mrem}$. 



\subsection{SUMMARY OF POTENTIAL RADIATION DOSE AND RISK ESTIMATES}

\section{1 $\quad$ Dose Estimates}

The dose to an individual from drinking water containing radionuclides associated with Plot M can be estimated employing the DOE methodology. If a hypothetical individual were exposed continuously to hydrogen-3 at various locations near Plot $\mathrm{M}$, the dose could be estimated. Assuming a person drank water from Location \#9 or the seep (Location \#6), or drank water from well \#5160, the dose from exposure for all of 2003 at the maximum and annual average concentrations is collected in Table 4.1. This scenario assumes that the individual's sole source of water is at the identified location.

A more meaningful estimation is for the occasional visitor to the Plot $\mathrm{M}$ area. Assuming a visitor drinks one liter of water from the surface stream or picnic wells, the dose from this exposure is estimated and presented in Table 4.2. The maximum total dose received by an occasional visitor is the combination of surface water and drinking water from the Red Gate Woods North Well (\#5160). This maximum dose would be 0.0001 mrem per visit.

In order to put the doses into perspective, comparisons can be made to annual average doses received by the public from natural or other generally accepted sources of radiation. These are listed in Table 4.3. It is obvious that the magnitude of the doses potentially received near Plot $\mathrm{M}$ from residual radioactive substances remaining from work conducted in this area are insignificant compared to these sources.

\section{2 $\quad$ Risk Estimates}

Risk estimates of possible health effects from radiation doses to the public from Plot $M$ have been made to provide another perspective in interpreting the radiation doses. 
TABLE 4.1

Dose From Continuous Exposure to Hydrogen-3 at Selected Locations, 2003

\begin{tabular}{|c|c|c|c|c|}
\hline \multirow{2}{*}{ Pathway } & \multicolumn{2}{|c|}{ Maximum } & Annual Average & $\begin{array}{c}\text { Average } \\
\text { Carcinogenic }\end{array}$ \\
\hline & Conc & Dose & Conc & Risk \\
\hline
\end{tabular}

Surface Water

\begin{tabular}{|c|c|c|c|c|c|c|c|}
\hline & Seep & $4.1 \mathrm{nCi} / \mathrm{L}$ & 0.2 mrem/y & $2.7 \mathrm{nCi} / \mathrm{L}$ & $0.1 \mathrm{mrem} / \mathrm{y}$ & 100 mrem/y & $9 \times 10^{-8}$ \\
\hline 总 & Location \#9 & $1.3 \mathrm{nCi} / \mathrm{L}$ & 0.06 mrem/y & $0.8 \mathrm{nCi} / \mathrm{L}$ & $0.04 \mathrm{mrem} / \mathrm{y}$ & 100 mrem/y & $4 \times 10^{-8}$ \\
\hline
\end{tabular}

Well Water

Red Gate Woods

North (\#5160)

$1.78 \mathrm{nCi} / \mathrm{L} \quad 0.082 \mathrm{mrem} / \mathrm{y} \quad 1.06 \mathrm{nCi} / \mathrm{L} \quad 0.048 \mathrm{mrem} / \mathrm{y} \quad 100 \mathrm{mrem} / \mathrm{y} \quad 3 \times 10^{-8}$ 
TABLE 4.2

Estimates of Hydrogen-3 Exposures to a Casual Visitor to Plot M, 2003

\begin{tabular}{|c|c|c|c|c|c|}
\hline Pathway & Quantity & Maximum Dose & Annual Average & $\begin{array}{c}\text { DOE } \\
\text { Dose Limit }\end{array}$ & $\begin{array}{c}\text { Average } \\
\text { Carcinogenic Risk }\end{array}$ \\
\hline \multicolumn{6}{|l|}{ Surface Water } \\
\hline $\begin{array}{l}\text { Seep } \\
\text { Location \#9 }\end{array}$ & $\begin{array}{l}\text { One Liter } \\
\text { One Liter }\end{array}$ & $\begin{array}{l}0.0003 \text { mrem } \\
0.00008 \text { mrem }\end{array}$ & $\begin{array}{l}0.0001 \text { mrem } \\
0.00005 \text { mrem }\end{array}$ & $\begin{array}{l}100 \mathrm{mrem} / \mathrm{y} \\
100 \mathrm{mrem} / \mathrm{y}\end{array}$ & $\begin{array}{l}1 \times 10^{-10} \\
3 \times 10^{-11}\end{array}$ \\
\hline \multicolumn{6}{|l|}{ Well Water } \\
\hline $\begin{array}{l}\text { Red Gate Woods } \\
\text { North (\#5160) }\end{array}$ & One Liter & 0.0001 mrem & 0.00006 mrem & $100 \mathrm{mrem} / \mathrm{y}$ & $4 \times 10^{-11}$ \\
\hline
\end{tabular}


TABLE 4.3

Annual Average Dose Equivalent in the U. S. Population*

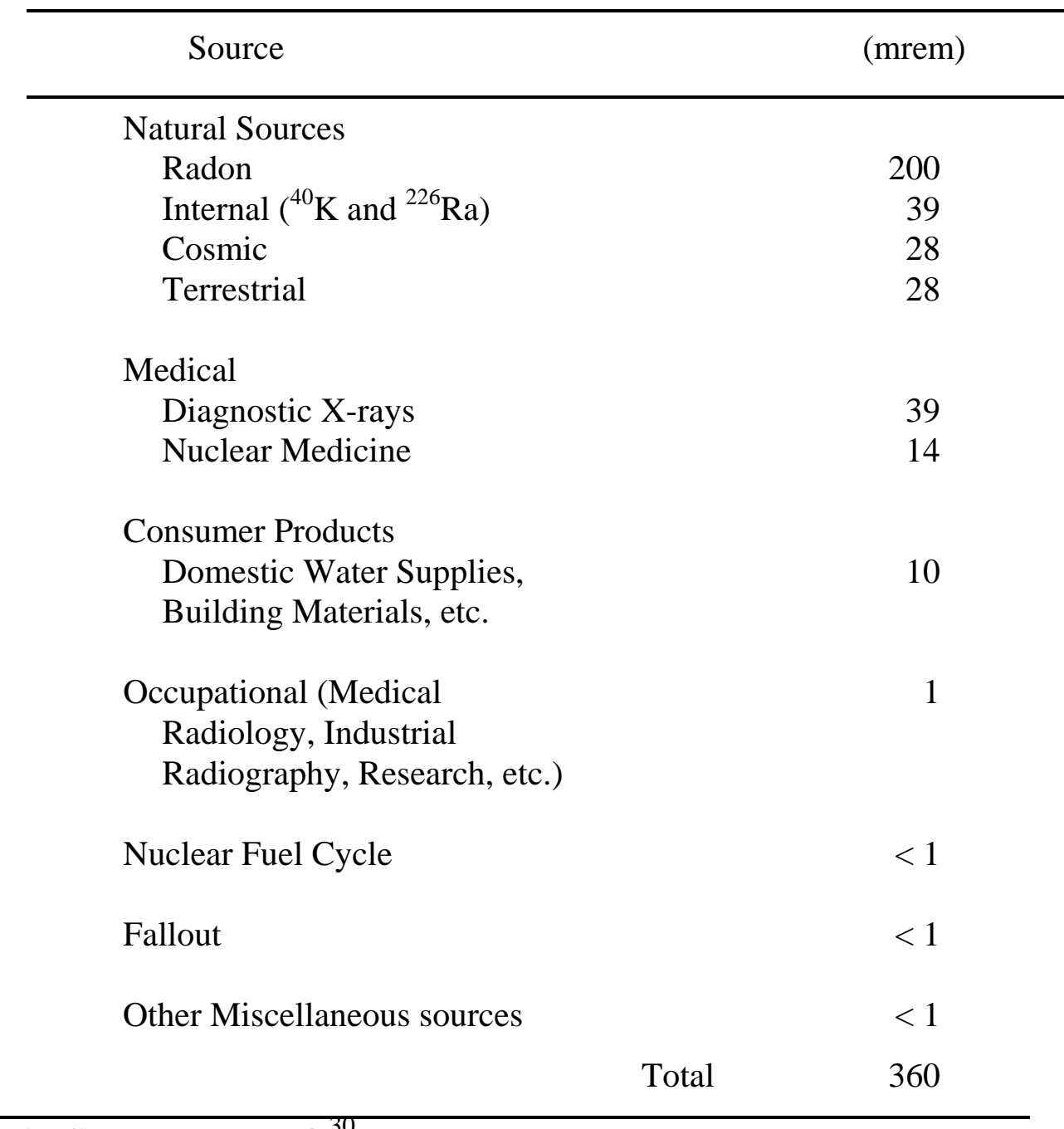

*NCRP report No. $93 .{ }^{30}$ 
Estimates for carcinogenic risk, the risk of contracting cancer from these exposures, is included in Table 4.1 and Table 4.2 for the average exposure scenario. Based on the BIER V report, ${ }^{31}$ a dose of one mrem/y equates to an increased risk of $7 \times 10^{-7}$. This conversion ratio is used in these tables. The risks are estimated to be in addition to the normal incident rate of cancer in the general population. For example, a carcinogenic risk of $10^{-7}$ would mean one additional cancer to 10,000,000 people exposed under the prescribed conditions. The EPA environmental protection standards are generally based on an acceptable risk between $10^{-4}$ and $10^{-6}$. This would imply that a risk of greater than $10^{-4}$ would be unacceptable and a risk of less than $10^{-6}$ would be acceptable. Examination of Table 4.1 indicates that even under the very conservative assumptions of sole source use of the water at Plot $\mathrm{M}$ annual average concentrations, the risk is less than the EPA recommendation. For the Table 4.2 hypothetical dose to an occasional visitor of $0.00001 \mathrm{mrem}$, the risk would be about $10^{-11}$. The risk from exposure to radionuclides at Plot $\mathrm{M}$ can be compared to the risk associated with various events. A few examples are collected in Table 4.4. The risk from the naturally-occurring sources of radioactivity listed in Table 4.3 is estimated to be about one additional cancer in a population of 8,000. Therefore, the monitoring program results have established that radioactivity at Plot $\mathrm{M}$ is very low and does not endanger the health or safety of those living in the area or visiting the site. 


\section{TABLE 4.4}

Risk of Death From Various Events

\begin{tabular}{ll}
\hline Cause & Risk \\
\hline Lightning Strike & $5 \times 10^{-8}$ \\
Tornado & $1 \times 10^{-7}$ \\
Flood & $1 \times 10^{-7}$ \\
Hurricane & $2.5 \times 10^{-7}$ \\
Drowning & $8 \times 10^{-6}$ \\
Air Travel & $3 \times 10^{-6}$ \\
Firearms & $2 \times 10^{-6}$ \\
\hline
\end{tabular}




\subsection{REFERENCES}

1. Golchert, N. W. and Sedlet, J., Formerly Utilized MED/AEC Sites Remedial Action Program Radiological Survey of Site A, Palos Park Forest Preserve, Chicago, Illinois, U. S. Department of Energy Report DOE/EV-0005/7 (April 1978).

2. Golchert, N. W., Sedlet, J., and Hayes, K. A., Environmental Surveillance of the Palos Park Forest Preserve, Argonne National Laboratory Report ANL-83-6 (January 1983).

3. Golchert, N. W. and Sedlet, J., Site Surveillance and Maintenance Program for Palos Park Report for 1982, Argonne National Laboratory (available from the authors) (April 1984).

4. Golchert, N. W. and Sedlet, J., Site Surveillance and Maintenance Program for Palos Park Report for 1983, Argonne National Laboratory (available from the authors) (June 1984).

5. Golchert, N. W. and Sedlet, J., Site Surveillance and Maintenance Program for Palos Park Report for 1984, Argonne National Laboratory (available from the authors) (April 1985).

6. Golchert, N. W. and Sedlet, J., Site Surveillance and Maintenance Program for Palos Park Report for 1985, Argonne National Laboratory Report ANL-86-25 (April 1986).

7. Golchert, N. W., Site Surveillance and Maintenance Program for Palos Park-Report for 1986, Argonne National Laboratory Report ANL-87-8 (April 1987).

8. Golchert, N. W., Site Surveillance and Maintenance Program for Palos Park - Report for 1987, Argonne National Laboratory Report ANL-88-12 (April 1988). 
9. Golchert, N. W., Site Surveillance and Maintenance Program for Palos Park-Report for 1988, Argonne National Laboratory Report ANL-89/7 (April 1989).

10. Golchert, N. W., Surveillance of Site A and Plot M - Report for 1989, Argonne National Laboratory Report ANL-90/7 (April 1990).

11. Golchert, N. W., Surveillance of Site A and Plot M - Report for 1990, Argonne National Laboratory Report ANL-91/2 (May 1991).

12. Golchert, N. W., Surveillance of Site A and Plot M - Report for 1991, Argonne National Laboratory Report ANL-92/13 (May 1992).

13. Golchert, N. W., Surveillance of Site A and Plot M - Report for 1992, Argonne National Laboratory Report ANL-93/4 (May 1993).

14. Golchert, N. W., Surveillance of Site A and Plot M - Report for 1993, Argonne National Laboratory Report ANL-94/9 (May 1994).

15. Golchert, N. W., Surveillance of Site A and Plot M - Report for 1994, Argonne National Laboratory Report ANL-95/7 (May 1995).

16. Golchert, N. W., Surveillance of Site A and Plot M - Report for 1995, Argonne National Laboratory Report ANL-96/2 (June 1996).

17. Golchert, N. W., Surveillance of Site A and Plot M - Report for 1996, Argonne National Laboratory Report ANL-97/5 (May 1997).

18. Golchert, N. W., Surveillance of Site A and Plot M - Report for 1997, Argonne National Laboratory Report ANL-98/1 (May 1998). 
19. Golchert, N. W., Surveillance of Site A and Plot M - Report for 1998, Argonne National Laboratory Report ANL-99/2 (May 1999).

20. Golchert, N. W., Surveillance of Site A and Plot M - Report for 1999, Argonne National Laboratory Report ANL-00/3 (May 2000).

21. Golchert, N. W., Surveillance of Site A and Plot M - Report for 2000, Argonne National Laboratory Report ANL-01/1 (May 2001).

22. Golchert, N. W., Surveillance of Site A and Plot M - Report for 2001, Argonne National Laboratory Report ANL-02/1 (May 2002).

23. Golchert, N. W., Surveillance of Site A and Plot M - Report for 2002, Argonne National Laboratory Report ANL-03/1 (May 2003).

24. U. S. Department of Energy, "Radiation Protection of the Public and the Environment," DOE Order 5400.5, February 8, 1990.

25. U. S. Environmental Protection Agency, "National Primary Drinking Water Regulations," 40 CFR Part 141.

26. U. S. Department of Energy, "Environmental Regulatory Guide for Radiological Effluent Monitoring and Environmental Surveillance," DOE/EH-0173T, January 1991.

27. International Commission on Radiological Protection, "Reference Man: Anatomical, Physiological, and Metabolic Characteristics," ICRP Publication 23, Pergamon Press, New York, NY (1975).

28. U. S. Department of Energy, "Internal Dose Conversion Factors for Calculation of Dose to the Public," DOE/EH-0071, July 1988. 
29. Nicholas, J. R. and Healy, R. W., "Hydrogen-3 Migration From a Low-Level RadioactiveWaste Disposal Site Near Chicago, Illinois," U. S. Geological Survey Water-Supply Paper 2333, 1988.

30. National Council on Radiation Protection and Measurements, Ionizing Radiation Exposure of the Population of the United States, NCRP Report No. 93, September 1, 1987.

31. Committee on Biological Effects of Ionizing Radiation, Health Effects on Populations of Exposure to Low Levels of Ionizing Radiation - BEIR V Report, National Academy Press, Washington, 1990.

32. Golchert, N. W., and Kolzow, R. G., Argonne National Laboratory-East Site Environmental Report for Calendar Year 2002, Argonne National Laboratory Report, ANL-03/2 (August 2003).

33. U. S. Environmental Protection Agency, 1986, RCRA Ground Water Monitoring Technical Enforcement Guidance Document, OSWER-9950.1, Office of Solid Waste and Emergency Response, Washington, DC. 


\subsection{APPENDICES}

\subsection{Quality Assurance Program}

All nuclear instrumentation is calibrated with standardized sources obtained from or traceable to the U. S. National Institute of Standards and Technology (NIST). The equipment is checked prior to the sample measurements with secondary counting standards to insure proper operation. Samples were periodically analyzed in duplicate or with the addition of known amounts of a radionuclide to check precision and accuracy. Intercomparison samples distributed by the DOE Environmental Measurements Laboratory Quality Assurance Program, a semi-annual distribution of three different sample matrices containing various combinations of radionuclides are analyzed. The results of our participation in this program for 2002 are published in ANL-03/2. ${ }^{32}$

Many factors enter into an overall quality assurance program other than the analytical quality control discussed above. Representative sampling is of prime importance. Appropriate sampling protocols are followed for each type of sampling being conducted. Water samples are pre-treated in a manner designed to maintain the integrity of the analytical constituent. For example, samples for trace radionuclide analyses are acidified immediately after collection to prevent hydrolytic loss of metal ions and filtered to reduce leaching from suspended solids.

The monitoring wells are sampled using the protocols listed in the Resource Conservation and Recovery Act (RCRA) Ground Water Monitoring Technical Enforcement Guidance Document. ${ }^{33}$ The volume of water in the casing is determined by measuring the water depth from the surface and the depth to the bottom of the well. This latter measurement also determines whether siltation has occurred that might restrict water movement in the screen area. For those wells in the glacial drift that do not recharge rapidly, the well is emptied and the volume removed is compared to the

calculated volume. In most cases, these volumes are nearly identical. The well is then sampled by bailing with a Teflon bailer. If samples for parameters such as priority pollutants are collected, field parameters for these samples ( $\mathrm{pH}$, specific conductance, redox potential, and temperature) are measured per well volume while purging. Most samples are collected for radiological analyses only. 
For samples in the porous, saturated zone which recharge rapidly, three well volumes are purged using submersible pumps. If field parameters are measured, samples are collected as soon as these readings stabilize. All samples are placed in precleaned bottles, labeled, and preserved. All field measurement and sampling equipment is cleaned by field rinsing with Type II deionized water. The samples are transferred to the analytical laboratory along with a computer floppy disk which generates a one-page list of all samples. This list acts as the chain-of-custody transfer document.

\subsection{Applicable Standards}

The standard that is relevant to this study is the DOE Order 5400.5 which established a dose

limit of $100 \mathrm{mrem} / \mathrm{y} .{ }^{24}$ The dose limit and dose calculation methodology are applicable to all media: surface water, deep holes, boreholes, and drinking water. The EPA drinking water standard ${ }^{25}$ is not applicable to the picnic wells since they do not meet the definition of a public water system. However, the EPA standard of $20 \mathrm{nCi} / \mathrm{L}$ for hydrogen-3 may be useful for some comparison purposes.

\subsection{Analytical Methods}

The analytical methods used to obtain the data in this report are the same as those used in ANL$03 / 2^{32}$ 


\subsection{Distribution for ANL-04/1}

$\underline{\text { Internal }}$

B. Bowen

A. B. Cohen

T. M. Davis

A. T. Fracaro

N. W. Golchert (25)

M. A. Kamiya

R. G. Kolzow

W. D. Luck

D. A. Milinko

R. E. Piorkowski

J. L. Tucker

R. A. Wynveen

TIS File

$\underline{\text { External }}$

ANL-E Library

ANL-W Library, AW-IS

S. Countiss, DOE Carlsbad Area Office

L. McGee, DOE Office of Legacy Management

A. Kleinrath, DOE Grand Junction Office (10)

S. L. Heston, DOE Chicago Operations Office

B. J. Quirke, DOE Chicago Operations Office

R. Allen, Illinois Emergency Management Agency

J. Barnett, U. S. Environmental Protection Agency, Region V

Bedford Park Public Library

T. Hyde, U. S. Environmental Protection Agency

T. Kelleher, Chicago District, Corps of Engineers

R. LaMort, Cook County Board of Commissioners

Librarian, Illinois Emergency Management Agency

Mayor of Willow Springs

M. McMullan, U. S. Environmental Protection Agency, Environmental Review Branch

C. Merenowicz, Forest Preserve District of Cook County

J. R. Nicholas, U. S. Geological Survey

G. Wright, Illinois Emergency Management Agency

L. Regner, U. S. Environmental Protection Agency, Federal Facility Coordinator

S. Shemanski, Cook County Department of Public Health

C. Smith, Illinois Environmental Protection Agency

D. Weber, Forest Preserve District of Cook County 
6-4 